Opuscula

Annual of the Swedish Institutes at Athens and Rome<smiles>[10BH2]</smiles> 


\section{A moving story about exotica: objects' long-distance production chains and associated identities at Tiryns, Greece}

\begin{abstract}
Studying materials through a chaine opératoire approach is common practice in studying craft activities. Whilst unravelling a chain of production can be very rewarding, many issues still arise: can all the steps be captured even when no material evidence is present, i.e. how can we approach production chains in the case of inconsistently or partially preserved material in settlement contexts? How may the steps that we are able to observe be contextualized in order to inform us about interconnected activities? In our research project carried out at Tiryns, Greece, we map certain steps through the production and consumption journey of a series of objects and materials, some of which have been referred to as "exotica". Our aim was to understand the life histories of those specific items, and with that, those of the people associated with them. In problematizing the etic category of exotica, this paper investigates patterns of movement that transcend the pure material aspect. By considering the technological and social networks that are the prerequisite for the movements of materials, whether during production, circulation or consumption, or all together, we can analyse the full value and meaning of these materials. We suggest that terms such as local and non-local need to be clearly defined and contextualized, and to be of explanatory value to the networks in which they are implicated.
\end{abstract}

\section{Exotica in archaeology}

Questions of identity and social distinction seem intricately interwoven with exotica or exotic materials, objects and practices. Within the archaeological discourse, "exotica" were recently defined as "any foreign as opposed to indigenous materials and products", and as "symbolic tools of distinction, primarily used in contexts of competition". ${ }^{1}$ Recent in-

\footnotetext{
1 Vianello 2011, vii. The Oxford English Dictionary (hereafter OED) defines "exotica" as follows (summarized): "Objects considered interesting because they are out of the ordinary, originating from a distant foreign country. Origin: 19th century: from Latin, neuter plural of exoticus 'foreign'". The same dictionary also characterizes exotic as (summarized): "Originating in or characteristic of a distant foreign country: exotic
}

terviews revealed that exotica were recognized in a wide variety of phenomena (Table 1). The way in which individuals characterized exotica was equally revealing (Table 2). People from different geographical and social backgrounds who participated in the interviews ${ }^{2}$ seemed to agree on many of the characteristics surrounding exotica, but not necessarily on what exotica are or what an exotic item represents. The way people thus view exotica seems interconnected with how they ascribe value to materials, items and practices that are different from their own and familiar material environments, as also evidenced in the interviews, from which it was clear that exotica did not always equal high value. Hence, as archaeologists our value ascriptions are likely to be different from what

birds, plants, places, attractive or striking because colourful or out of the ordinary: youths with exotic haircuts, of a kind not ordinarily encountered (especially of metals or fuels), specially produced (our emphasis): exotic chemicals. Origin: 16th century: via Latin from Greek: $\varepsilon^{\xi} \xi \omega \tau$ wóss: foreign, "है $\xi \omega$ : outside", www.oed.com, accessed 12/05/2012. Another way to categorize such items is: imported inanimate items, fauna and flora (dead or alive, and their respective parts), and humans that were captured or imported by force, for the latter group, see Michaelidou \& Voutsa 2005.

2 The interviews were conducted between March 2012 and February 2013. 50 people from varying age groups (from 19-70+ years old) were asked the same two questions, resulting in Tables 1-2. Half of the respondents answered orally in a discussion forum, others in reply to a typed questionnaire where the questions, their age group and their professional/educational background were asked. People of nine different nationalities and countries took part and the majority of the respondents ( 48 of the 50) fell in the age group of 20-30 years old. The groups targeted were chosen from the immediate vicinity of the interviewer and formed student groups of different nationalities and continents, study backgrounds and degree levels. Other groups targeted were colleagues and acquaintances chosen in different age groups and from different educational backgrounds. The lowest educational degree obtained was a high school diploma; the highest was a doctorate, with other degrees in between. 
Table 1. Interview results: examples of exotica (interview results and documentation by $A$. Brysbaert).

\begin{tabular}{|l|l|}
\hline 1 & British beers, Indian spices, colourful cocktails \\
\hline 2 & African art \& people, ethnic/Indonesian furniture \\
\hline 3 & Far-away places, palm beaches, Asian temples \\
\hline 4 & Elephants \\
\hline 5 & Strange and colourful plants, flowers and fruits \\
\hline 6 & Colourful birds, unusual animals \\
\hline 7 & Rare people \\
\hline 8 & Penis holders, shrunken heads \\
\hline 9 & Bavarian traditional costumes \\
\hline 10 & Meteorites, space ships \\
\hline
\end{tabular}

Table 2. Interview results: characteristics of exotica (interview results and documentation by A. Brysbaert).

\begin{tabular}{|l|l|}
\hline 1 & Felt to be from far away geographically or culturally \\
\hline 2 & Something hard to get, expensive, rare \\
\hline 3 & $\begin{array}{l}\text { Something that falls beyond our traditional viewpoint which } \\
\text { is culturally determined }\end{array}$ \\
\hline 4 & Something astonishing, surprising \\
\hline 5 & Unusual in form, shape or function \\
\hline 6 & Something unfamiliar \\
\hline 7 & It may cause envy, irritation, curiosity, awe, rejection \\
\hline 8 & $\begin{array}{l}\text { Something that tells an unusual story, that illustrates } \\
\text { unknown practices and behaviours }\end{array}$ \\
\hline 9 & Something magical, poisonous, dangerous \\
\hline
\end{tabular}

people in the past may have thought about specific objects or features and what was perceived as local versus non-local. ${ }^{3}$

Exotica as a specific type of material or object also seems closely linked to cultural mixtures of materials from different origins and their interconnection with people's mobility patterns and cultural encounters. As such, exotica can be associated with the concepts of hybridization and creolization, ${ }^{4}$ terms that may imply mobility, technology transfer, material culture exchange and several forms of appropriation. ${ }^{5}$

From the available literature on exotica in archaeology, ${ }^{6}$ the types of context and aspects of value given to such items ${ }^{7}$ seem to play a role in determining what can be considered as exotica. Most of this is determined from an etic western viewpoint. Crucial in studying exotica and their meaning is thus

\footnotetext{
3 Cf. van Dommelen \& Rowlands's (2012, 25-27) discussion on what they call an "exclusionist ontology".

4 The terms have their roots in colonial discourses and have been heavily discussed in the post-colonial literature subsequently, see van Dommelen 2006, esp. 119; van Dommelen \& Rowlands 2012.

5 See Maran 2012 on aspects of appropriation.

6 See for instance the recent edited volume by Vianello 2011.

Beauty, rarity and distance, functionality, ritual connotation: Helms 1993, 3-4, 6, 8, 33.
}

discussing aspects of value. ${ }^{8}$ Both exotica and value are linked to aspects of exchange. Voutsaki follows Marcel Mauss's definition of exchange as a total social phenomenon which consists of "... the flow of material resources [together with] ... a complex network of prestations and services that circulate along the basic articulations of the community: the kin relations and the power structure". Exchange in pre-monetary societies, especially gift-exchange, she maintains, is crucial to social competition because it created bonds of dependence and obligation. Exotica were often tightly linked with societal elites collecting such items from afar (e.g. Hatshepsut's expeditions to Punt), but also in acquiring them ${ }^{10}$ through the process of gift exchange, as the Amarna letters amply indicate. ${ }^{11}$ Foster illustrated through textual, iconographic and archaeological evidence that the Ancient Egyptian and Near Eastern rulers mentioned in their texts and on wall decorations that exotica-rare, transmuted, and transformed, live or inanimatewere all vital to elite groups since these items confirmed the king's rule, and proved his political and economic capabilities in far-away regions. ${ }^{12}$ Such items were taken to prove this and their depiction formed mental maps and texts metaphorically linking such items to the ruler's heroic and mythical presence. In this case, the value embedded in exotica seems to lie in the differences in exclusivity of objects and material in association with other goods because these give clues to the variations in social roles and cultural significance of these exotic items. Moreover, the motivations that people may have had in past contexts (which may not always be that different from modern ones) to acquire exotica may have given exotica additional values and meanings. These can be broadly placed in three categories. The first is practical: such items, objects, material or technologies are deemed better for certain functions or of superior quality than local ones. The second is social: they may improve individual status and increase social inequality; and the third is symbolic: political, ideological and ritual/religious reasons that increase social inequality, thus distinction. ${ }^{13}$

\footnotetext{
8 Bevan $2007,16-18$ proposes to investigate quantity, quality and diversity of artefact classes to reconstruct plausible emic value systems or classifications.

9 Voutsaki 1995, 7-8.

10 Foster 2008, 328.

11 Moran 1992.

12 Foster 2008, 328-331.

13 The specific items acquired may not do any of the above with the intent to emulate other cultural (and "superior") thoughts and behaviours, instead, they may synthesize a shared cosmological set of viewpoints or values, both by people who adopted the foreign thing and by those who are used to it already (after van Dommelen \& Rowlands 2012, 27). This allows for those who do adopt it into their material world, to be equals in the equation that is formed through any of the relational contacts, whether technical, social or both.
} 
The three categories easily blur into one since they interweave, while social and symbolic reasons are, in essence, practical motivations too. These categories, however, do not solve all issues encountered concerning the uncritical continuous usage of exotica in archaeological contexts. For example, it does not consider at all how the individual who appropriated new items within their material world, whether elite or otherwise, perceived and understood those items. Such expressions are based, according to Legarra Herrero, ${ }^{14}$ on pure assumptions, rather than on studies based squarely in their specific context. This brings us back to Voutsaki who sees the value of labour, involved in the production of prestige items in pre-monetary contexts, in the aesthetic embellishment and semantic virtuosity. She, therefore, understands labour value as the product of exclusive, often ritualized skills rather than invested energy. ${ }^{15}$ It may well be people's perceived foreignness of specific objects that displays a connotation with appreciation and thus provided the objects with value and cultural significance. Such perceptions may be based on stylistic, iconographic, technical, material and functional properties of such items, and their connection with other associated items and within the contexts in which they were produced, distributed and consumed.

For the purpose of the present article, we define exotica as something that implies, first, a geographically distant location of origin or is thus non-local, and bears a certain level of value due to its scarcity, whether natural, cultural or political. ${ }^{16}$ Moreover, according to the $O E D$ definition cited above exotic presently can also simply refer to something out of the ordinary or something specially produced. This was made very clear in the interviews: people may find things exotic even if they had no high value. Thus, modern archaeological characterizations of items as non-local and/or valuable may not always be adequate notions of something exotic and we, therefore, suggest to also extend this cautious understanding to past concepts of exotica. For example, originally exotic jewellery may have been passed down generations as heirlooms: people may have become totally familiar with specific items (in contrast to finding them out of the ordinary) and thus not have considered them exotic any longer. We contend that people's contextualized actions, their gestures and constant interactions with their material surroundings are crucial to any definition of exotica and thus to the subsequent discussion since it is the contextual approach which may suggest ever-dynamic value shifts of such objects and materials, depending on when and where specific materials were interacted with. The main aims of our article are therefore twofold.

14 Legarra Herrero 2011, 269.

15 Voutsaki 1995, 9.

16 Voutsaki 1995, 11
First, we aim to explore the usability of the concept of exotica in the contextualized analyses of three workshop areas (case studies 1-3 below) in Late Bronze Age Tiryns (Argolid, Greece).$^{17}$ Through a holistic material approach we dissect the often uncritically used concept of exotica in archaeological contexts, into closely interlinked sets of objects and materials that help to dissolve the inflexible dichotomy ${ }^{18}$ between local versus foreign. We thus allow for a much more nuanced way of looking at materials, objects, processes and practices by asking what these are and what they may have meant. Second, we aim to investigate the mechanisms and socio-economic strategies that several people involved in the production processes may have employed and manipulated to assign values to things, and why these strategies were employed as such. We thus inquire about people's social identity constructs and about different levels of perception.

This paper addresses these questions by employing a chaine opératoire approach to investigate the production processes of certain items from Tiryns. We aim to increase our understanding of how people at Tiryns may have perceived, allocated and reallocated values, social significance of items deemed exotic from our contemporary viewpoint and potentially by their prehistoric users, and how they may have determined something as being exotic within their daily interactive patterns, practices, and social strategies. ${ }^{19}$ The most obvious way to study exotica in the past may be to reconstruct past value creation or value ascription. Often, these high value objects were made upon specific demands for specific people. They were associated with prestige-building, thus enhancing a select group of people's social identities. The relation between value and an individual's standing are mutually defined since, in gift exchange, the perceived value of goods offered and a recipient's prestige are created simultaneously and are mutually acknowledged. Value, it seems, relies on the intrinsic properties of, on the labour towards, and on the history of each object, thus on its past and "personality", as it moves through circulation networks. Value is thus accumulative and increases from production through the various steps of exchange or circulation into its consumption, seen here as a pre-monetary mode of (symbolic) accumulation and as a mechanism for social

\footnotetext{
17 http://www.tracingnetworks.ac.uk/content/web/cross_craft_interaction.jsp.

18 A hallmark of post-colonial theory is to recognize ambiguity in cultural contexts when it is removed from binary oppositions such as local versus foreign, import versus export, after Counts 2008, 112.

19 Foster 2008 indicates how people in the Egyptian context were referring to certain specific objects and materials as exotic so the concept is not just contemporary but of course the objects or practices signified as such are highly culture-specific and context-dependent. We argue that the difficulty does not lie in the concept per se but rather in reconstructing what may have constituted or have been contextualized as exotic at any given time in the past.
} 
differentiation. ${ }^{20}$ Complementary to a value-based approach to exotica, however, is studying the concept from a scarcityapproach: objects that only occur rarely but may not be of intrinsic value or apparently gain added value, may fall under the concept of exotica as well. These realizations fit extremely well with a chaine opératoire and cross-craft interaction approach to exotica since both methods allow for the study of such processes, of production and circulation, and of interwoven networks that link such items and people.

\section{Approaching the production of exotica}

Since our overall project of the workshops studies at Tiryns predominantly focuses on aspects of production as one part of the objects' biographies and their value assignment processes, a short excursion into the chaîne opératoire and cross-craft interaction approaches to ancient or pre-industrial technologies is required as they bear relevance to the discussions of our case study materials. The methods are employed to study the material left-overs found within the workshop areas, and based on these remains they allow us to reconstruct the processes in their production.

Technology, on one hand, consists of processes, tools, equipment, and skills, thus knowledge and practices, and forms, on the other, "the mutual relationship between people and things through skilled performance". ${ }^{21}$ It has also been defined as non-verbal forms of communication to unite or divide social groups. ${ }^{22}$ Technologies are thus, in essence, social phenomena with which everyone engages, consciously or unconsciously, in the present as well as in the past. Technologies shape materials and people, who, in turn, shape technologies. However, access to technical skill and knowledge relating to specific crafts seems to have been often restricted, probably best exemplified by the medieval guilds system of which one could become a member. After long years of intensive training with a master and after successfully completing a chef d'oeuvre that had to be approved by the master, the apprentice could become a journeyman for another lengthy period of time. During those years he continued to develop additional skills, those of management and leadership, before he had to produce a chef d'oeuvre élevé. If that was accepted, he was then considered skilled enough to take the master's place. These guild members created and maintained a strong sense of community, protected their craft, and were the crucial

\footnotetext{
20 Voutsaki 1997, 37-38. We also think, however, that value can also decrease at various points during the life history of objects, for instance from metal tool to metal scrap.

21 Ingold 1999.

22 Kenoyer 2000.
}

points of contact for workers on the move. They also managed a migrant's obligations towards newly encountered artisans. ${ }^{23}$ Technologies and craft activities can thus include or exclude. Those people, then, who obtained knowledge through journeys abroad (e.g. the journeymen, merchants, travelling artisans), may have been imbued with accumulative levels of prestige after each trip. Such prestige has also been associated with the capability of obtaining exotic raw materials, manufactured goods, animate and inanimate beings. ${ }^{24}$ There seems, thus, to be a link between technology, knowledge, social status and exotica or non-local items in certain contexts.

From the 1930s, the anthropologist André Leroi-Gourhan developed and employed a method which he called "the chaine opératoire of technological production". ${ }^{25}$ In the original French publications of the 1940s, he described processes rather than a set of linear actions or steps. ${ }^{26}$ These processes were both technologically and socially interwoven, processes that afforded ${ }^{27}$ the production of objects and features, but also of people and their relations. ${ }^{28}$ Leroi-Gourhan's original texts also exemplify and elucidate the complexities of production and consumption, aspects we encounter in studying archaeological materials and what we can make of these, both technologically and socially. ${ }^{29}$ Moreover, the social and sensory processes embedded in human interaction and communication with each other and materials while choosing, forming, distributing and consuming them, need emphasis. ${ }^{30}$ In a recent example, the intricacies of the ever changing rhythmic and repetitive movements or gestures ${ }^{31}$ needed to saw a plank, were brought home in a lively description showing how wood clearly interacts with the sawing hand, how it even dictates the sawing action required. This series of movements, the process of sawing the plank, is processional, not successional. ${ }^{32}$ The successful outcome of a well-sawn plank clearly depends on the expertise of the sawing hand, built up over time, with this material by repeating these movements over and over again.

\footnotetext{
Sennett 2008, 58-60.

After Helms 1988 and Knapp 1998.

Leroi-Gourhan 1964-1965.

26 For the latter, see e.g. Tykot 2011. Ingold 2011, 53 and Kuijpers 2012, 146, for instance, are referring, indirectly, to the chaine opératoire as a linear process, a sequence; this is too narrow a reading of LeroiGourhan's work, in our view.

27 Cf. Gibson 1979, 16-23 for a discussion on affordance in relation to his notions on medium, substances and surfaces.

28 See e.g. Schlanger 1994; Pfaffenberger 1992, 199; Dobres 2000; 2010.

29 Brysbaert 2011a; see also Naji \& Douny 2009, 414.

30 Brysbaert 2008, 47-48; see also Kuijpers 2012.

31 Gestures are crucial to Leroi-Gourhan's understanding of the chaine opératoire as well.

32 Ingold 2011, 53-54.
} 
A second aspect to this technological phenomenon is that no craft is conducted in isolation. While this is common sense, it remains worthwhile emphasizing this point in order to pay specific attention to it while studying archaeological materials. Cross-craft interaction, ${ }^{33}$ or the ways specific crafts are connected to others through materials, knowledge, skills and gestures, tools and equipment has frequently been identified in studies of the technology in painted plaster. ${ }^{34}$ Since people traditionally study archaeological remains by material category, such connections between crafts may easily be missed and unfortunately cross-craft studies are still not often conducted systematically and consciously. ${ }^{35}$ A good example of cross-craft interaction in material transfer is attested at Amarna in Egypt, where 18th Dynasty metallurgists supplied scraps of their copper working activities to the workshop next door where glass was being produced. Those scraps were subsequently used as a colouring agent to make blue coloured glass. ${ }^{36}$ Cross-craft interaction is not limited to a few craft activities. ${ }^{37}$ It is inherent to each and every craft activity or technology, as long as technologies and crafts are conceptualized as practices, be their outcome material or immaterial. In the same way, people are intrinsically interwoven through what they do, and how they interact, be it via musical performances or through specific modes of conduct. ${ }^{38}$

In approaching the material left-overs from the different Late Bronze Age activity area contexts in Tiryns through multiple chaînes opératoires and cross-craft interaction lenses, ${ }^{39}$ we try to uncover several dimensions of the encountered craft activities, including the social practices that accompany and motivate such craft activities, and their impact on people's lives. We thus specifically trace chaînes opératoires from mostly fragmentary finds in selected archaeological contexts to reconstruct past activities and practices where possible, and, in doing so, the dichotomy between the material and immaterial dissolves. In investigating material remains from this combined perspective, we attempted to classify the range of different production processes that may deliver an item with exotic connotations. As a starting point, we formulated certain expectations we had with regard to different production processes. Based on Laffineur's work we used these as a scale to characterize local and imported materials in our archaeologi-

33 Term coined by McGovern 1989; see also Brysbaert 2004; 2007; 2008.

34 Brysbaert 2004; 2008.

35 But see most recently: Thomas 2012.

36 For details, see Shortland 2000.

37 E.g. Foster 1989; Vickers 1989 for early examples of cross-craft interaction studies.

38 Brysbaert 2007; 2011a.

39 Brysbaert 2007; 2008; see also Brysbaert \&Vetters 2010. cal contexts. ${ }^{40}$ Five idealized production modes emerged, several of which are similar to Heymans and van Wijngaarden's categories:

Items produced elsewhere and imported: $:^{41}$ from a chaîne opératoire perspective, no direct material evidence pertaining to the production of such items will be found in the local context where it may have been consumed (e.g. lapis lazuli cylinder seals found in Thebes ${ }^{42}$ ).

Items produced locally with imported materials, in foreign or local styles: $:{ }^{43}$ parts of the chaine opératoire can be expected in the local context (e.g. ivory inlays and debris of ivory working from Mycenae $\left.{ }^{44}\right)$.

Items produced locally with local materials, imitating foreign objects: $: 5$ more or less the entire chaine opératoire debris can be expected in the local context, apart maybe from the initial raw material collection (see below for a discussion of the issue of what constitutes local in geographical terms, e.g. scarabs produced in Crete, in Egyptianizing style ${ }^{46}$ ).

Items produced locally with imported/local materials, by foreign artisans with knowledge of foreign technologies: the same amount and types of chaine opératoire left-overs may be expected in the local context as for category 3 (e.g. Mycenaean inlaid daggers ${ }^{47}$ ).

Items produced locally with local/imported materials by local artisans who possess specific skills (possibly learned elsewhere): the same amount and types of chaine opératoire left-overs may be expected in the local context as for category 3 (e.g. Mycenaean-style stone vessels found at Mycenae $\left.{ }^{48}\right)$.

While thought to be very helpful initially, these categories are not without problems and this became clear when studying Heymans and van Wijngaarden's low value exotica discussion, ${ }^{49}$ a category of materials that did not fit easily in the list above. We thus considered it crucial to unpick the different elements

\footnotetext{
40 Laffineur 2005, 53: who argues against the simple dichotomy of local versus import, a dichotomy which we did not find very helpful either.

41 Heymans \& van Wijngaarden 2011, 124: international goods; imports and exports.

42 Even though some may have been reworked locally from the original group: Porada 1981-1982, 4. This example already shows that the end of the production chain is not located at the primary use stage only and that several stages in the production chain of an object can change location easily.

43 Heymans \& van Wijngaarden 2011, 124: international goods; objects in native traditions that incorporate foreign stylistic or material elements.

44 E.g., the LM IB ivory workshop on the Royal Road in Knossos or the House of the Artisans in Mycenae, see Tournavitou 1995, 191-193.

45 Heymans \& van Wijngaarden 2011, 124: international goods; imitations and derivatives.

46 Pini 2000; Legarra Herrero 2011, 269

47 Laffineur 2005, 57.

48 Bevan 2007, 163-164.

49 Heymans \& van Wijngaarden 2011.
} 
of the chaines opératoires so that the exact meaning of what raw materials are, on the one hand, and manufactured goods, on the other, can be clearly defined. A raw material can best be described as the material which has not yet been worked for the purpose for which it has been acquired. The definition thus implies a specific timing and location that are important in the interpretation of the types of materials that may be found in workshop contexts, and the meaning they have in that specific context in order to identify the place as a proper workshop..$^{50}$ Heymans and van Wijngaarden are far from the only ones who understand ingots (glass or metal), as raw materials. This is not necessarily wrong but ingots can also be seen as the outcome of several steps in the process of producing finished glass objects such as beads or inlay pieces or metal items such as javelin heads. In the view of those who produced and transported the ingots, they can only be seen as manufactured goods. When these ingots reached the Aegean, the artisans, further processing them, likely saw these as the raw materials or half-finished items to be transformed into beads, inlays or javelin heads. This situation may become even more complex when recycled materials, as a starting point for production, are under consideration. The separation between a raw material, a finished good, and the many stages in between is thus dependent on people's viewpoints and their situatedness in specific contexts. An object or material can thus be a raw material, a half-finished product and a finished object, depending on its specific context of acquirement, production, distribution and consumption.

Value assignment to these materials and items is, therefore, also linked to this situatedness (or context) and may, as Voutsaki indicated, be accumulative, from situation to situation, or context to context. If we then try to fit, for example, the glass beads in one of the above five categories, they would fit both in category 1 (as far as the glass ingot production is concerned) and 2 (the actual shaping of the beads), and potentially even in 4 and 5. This demonstrates that trying to fit materials and items in specific categories of production modes may prove a vain attempt that may only work if such production modes, and thus the items under study, are de-contextualized. It is thus the wide array of, for instance, recycled materials in craft production that oppose the use and understanding of the chaîne opératoire concept as a linear process of consecutive steps. In this context, the notion thus forces us to consider it as a series of interwoven processes, or a network of practices, wherein people's interactions, skills and perceptions of their material surroundings are at the forefront. If we approach

50 See the categories described by Tournavitou 1988 to identify a space as a workshop space; see also Hasaki 2011. these exotica, whether of high or low value, ${ }^{51}$ from a chaine opératoire perspective, this allows us to study the human processes, and to take into account the gestures that transformed materials into finished objects. Thereby, we may also get one step closer in understanding how people allocated value to their material surroundings: first during production, but then also during the other spheres of an object's life, its distribution and consumption, its potential reuse $(s)^{52}$ up to its final discard.

\section{Workshops and activity areas in Late Bronze Age Tiryns}

The discussion of the following case studies focuses on archaeological remains from the acropolis at Tiryns (Fig. 1), situated on the fringe of the Argive plain. The site evolved from the middle of the second millennium $\mathrm{BC}$ to $c .1200 \mathrm{BC}$ into one of the most important Mycenaean palatial settlements and probably the major port of the Mycenaean core zone. The acropolis is divided into an Upper, Middle and Lower Citadel (Fig. 2) that were successively fortified in the 14 th-13th centuries BC. A multi-phase palace with a Mycenaean megaron developed on the Upper Citadel. Monumental architecture, such as the Western Staircase, the Eastern and Southern Galleries, and the so-called Syringes testify to the power and the external connections of the local elite during late palatial period. ${ }^{53}$ An extensive settlement existed in the plain surrounding the citadel during the palatial and the post-palatial periods. Tiryns as a central place during the palatial (c. 1400-1200 BC) and post-palatial periods (c. 1200-1050 BC), had farreaching connections to the eastern Mediterranean. ${ }^{54}$

The discussion on exotica in the present article is one part of a comprehensive review and analysis of workshop areas at Tiryns. ${ }^{55}$ The aim of that project is twofold. It is, firstly methodological: how do we identify a workshop and the differences within the range of workshops that existed? The Mycenaean workshop model by Tournavitou ${ }^{56}$ has been a useful starting

\footnotetext{
51 But see Voutsaki 1995, 9 on the complexity of value scales, symbolic value, and potential value differences embedded in production and circulation/exchange if controlled: given values can increase during circulation. She goes further in 1997, 37: "Value is created by and in the process of exchange, and not only at the moment of production."

52 See Philipps 2012 on Aegean jewellery.

53 Maran 2010; Brysbaert 2014b, in press.

54 Maran 2004b; Stockhammer 2008, 273-283; Vetters 2011b.

55 See for instance Brysbaert \& Vetters 2010; Brysbaert 2011a; 2011b; Vetters 2011b; Brysbaert 2013; 2014a, in press; Vetters \& Brysbaert, forthcoming. The final results of this study will appear in a co-authored monograph by the authors.

56 Tournavitou 1988.
} 


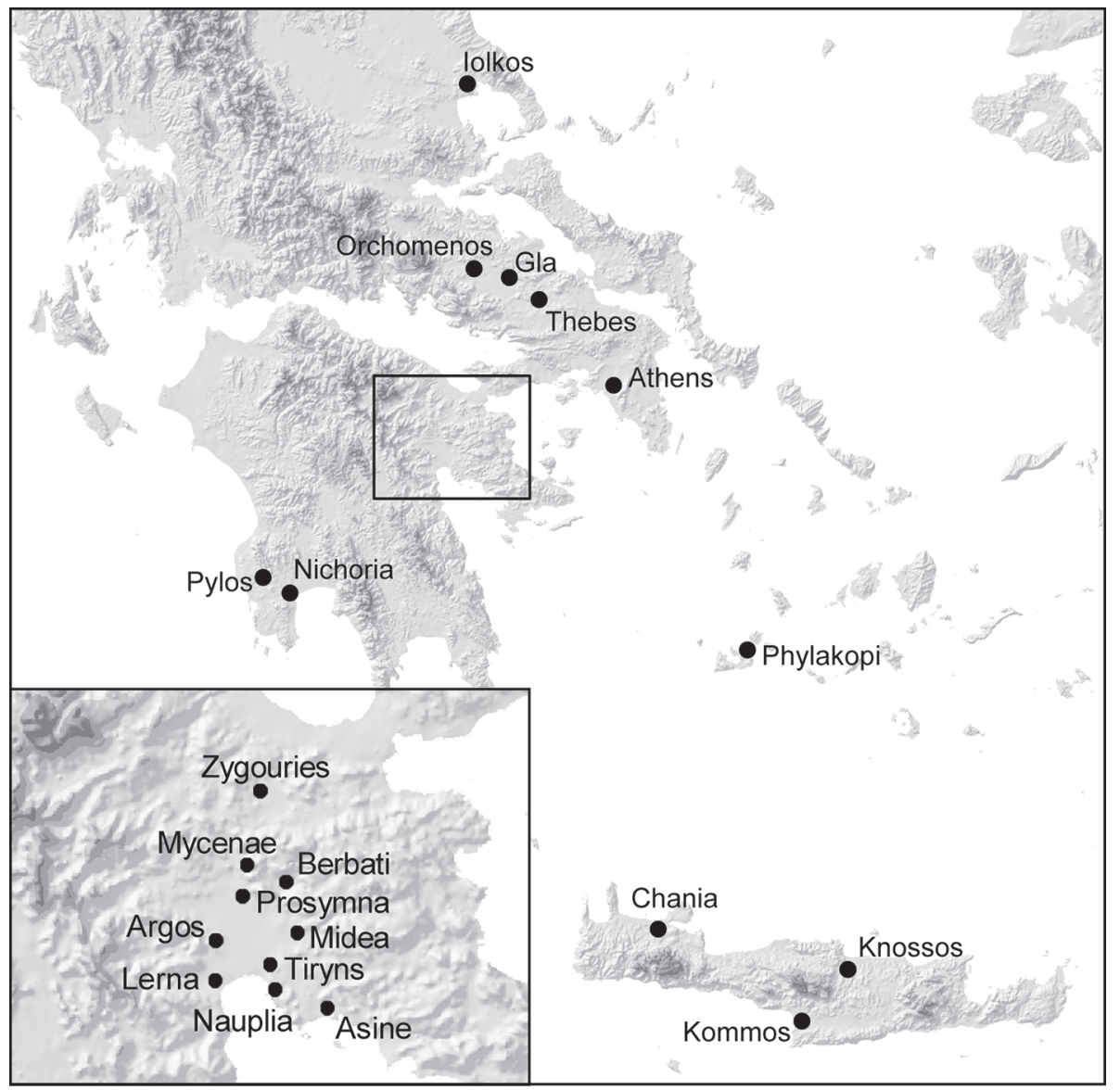

Fig. 1. Map of Greece with inset for the Argolid and Tiryns (map by Anavasi editions/Hans Birk, our modification).

point but, having tested this against the data from one of the Tiryns-based case studies, ${ }^{57}$ the model needs reconsideration and should only be used as a guide, not as a prescription on how to define and recognize Mycenaean workshops. Secondly, through investigating our case study materials, supplemented with comparanda of such objects found in workshop contexts from other published sites, we traced technological processes and investigated how these are represented on other sites with the aim of complementing our understanding of some of our own incomplete chaînes opératoires.

Since 2008, more than 1,200 objects have been studied at Tiryns, macroscopically and microscopically, and many via non-destructive instrumental analysis, more specifically by means of Laser-Induced Breakdown Spectroscopy which aided in the clarification of material identifications. ${ }^{58}$ All finds have been photographed using a variety of lenses. Their materials and function, their last usage, their context and

57 Brysbaert 2014a, in press.

58 In close collaboration with Dr D. Anglos, Dr P. Siozos and Dr A. Philippidis, based at FORTH-IESL, Heraklion, Crete. The result of this on-going work will be published separately. technologies, their preservation, and their conservation and post-excavation treatments have been described in detail. Information from data recording, contextual and stratigraphic analysis, as well as plotting the finds on phase distribution maps has proved useful in order to analyse where concentrations of specific find categories exist and what these patterns may have meant in the contexts in which they were found. We, therefore, examined all categories and materials present in four case studies from the Lower Citadel and Lower Town Northeast in Tiryns. ${ }^{59}$ The case studies were selected on the bases of their potential to study craft activities and because of chronological overlaps between them. This last factor was deemed important since we wanted to study diachronic similarities and changes in active craft production processes and practices, if and where possible. For each of the potential workshop case studies we investigated four questions. First, how do we detect workshop activities, what parameters indi-

59 This study covers all small finds and the architectural surroundings in which these were found, but we did not include the decorated and undecorated pottery since these are currently under study by other colleagues; we also had to take into account specific time restraints. 


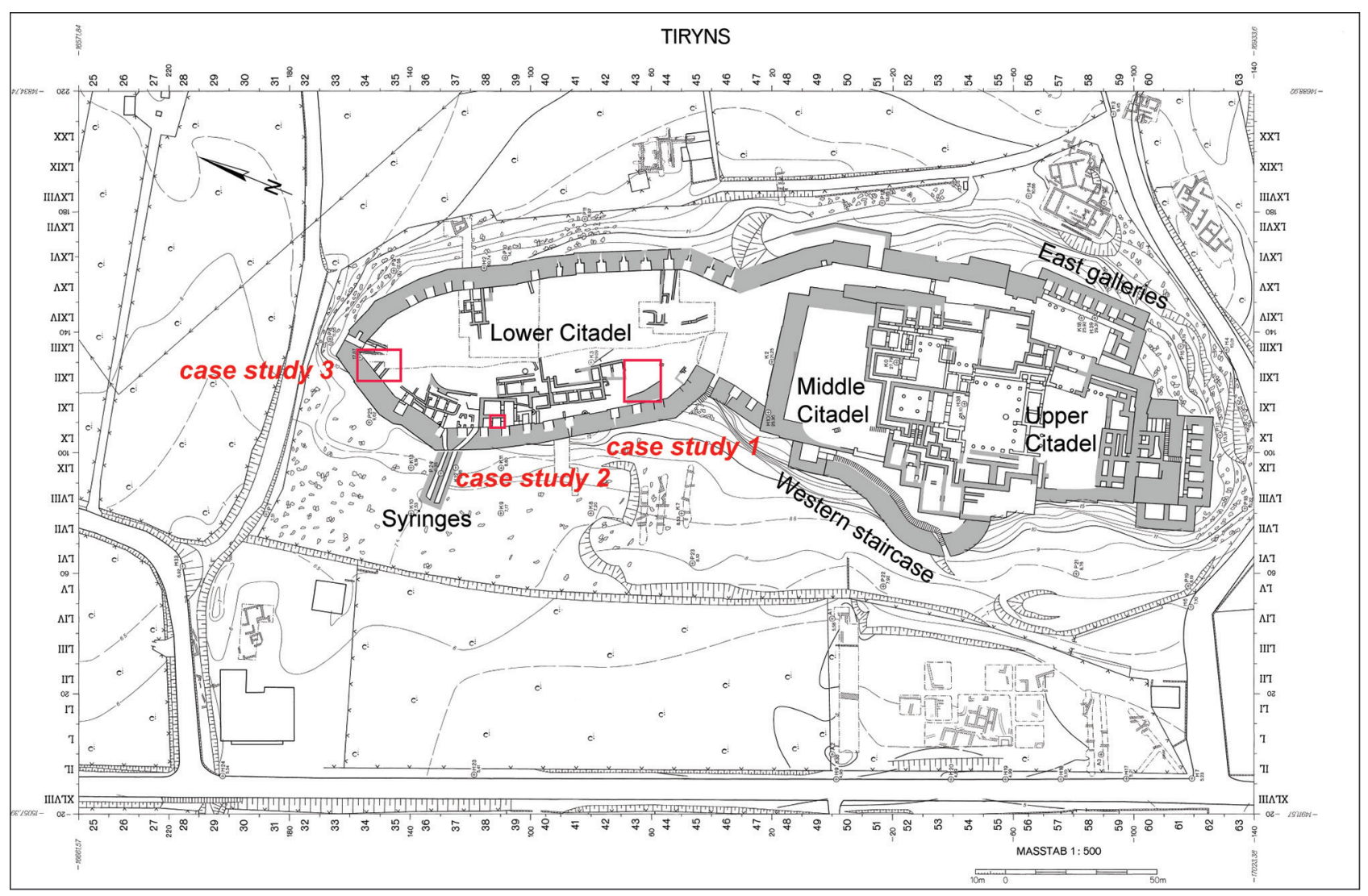

Fig. 2. General plan of Tiryns indicating the case studies mentioned in the text (general plan by Tiryns-archive, with kind permission by Joseph Maran, our modification).

cate a workshop, and how do we interpret the data? Second, how are workshop activities interlinked, not only in the portable material finds, but also in the installations, fixed facilities and its architecture? Third, what craft activities took place in each and how do we recognize these? What and where may inherent biases in the material record impede reconstruction of craft activities? And fourth, if more than one craft was present, do we have evidence of cross-craft interaction, technically and socially, and where does it show ?60

While these questions are not treated in this paper per se, they form the basis of our general investigation on craft activities in Tiryns from LH IIIB Early to LH IIIC Late. As a result of investigating our case study materials with these questions in mind, because of Tiryns' apparent presence as a node of contact in several interregional networks and its importance as a harbour in that period, ${ }^{61}$ we also investigated technological and social networks and practices that may have existed beyond the Aegean. As such we were, in a way, forced to pay

60 Cf. Brysbaert \& Vetters 2010.

61 Maran 2010, 722. close attention to a specific series of finds that have commonly been described in the literature as exotica or exotic. In order to test the exotica concept, and its attribution to these Tirynthian materials, we examined all small finds recovered from three of our case study workshop areas along several chaînes opératoires and analysed them in their respective architectural contexts. As such, we were in a position to reconstruct the potential technical and social practices and strategies, several of which may have reflected past connections to and attitudes (such as value assignments) towards what has been referred to until now as exotica. With this extra data we could assess the validity of employing the term exotica to these and other past contexts. ${ }^{62}$ Here, we present the materials, objects and features which we have studied in some detail, and contextu-

62 The material studied, however, is part of a settlement assemblage and thus does not derive from a closed depositional context as, for instance, material from a funerary context would. Therefore, we took into account the extent and state of preservation as well as the overall artefact concentrations to distinguish between secondary and primary deposition, where only the latter can be meaningfully linked to activities that may indicate left-overs from craft activities. 
Table 3. Lower Citadel Southwest, case study 1A-non-local materials or components in the LH IIIB Middle terrace house during the first occupation phase (hor. 16 a-16a50).

\begin{tabular}{|l|l|l|l|l|}
\hline TN-number & Find spot & Description & Stratigraphic horizon & Bibliography \\
\hline TN 784 & LXII 43/11 XVIc a13.12 & Egyptian blue lump & hor. 16 a2 & Rahmstorf 2008, 188, cat. no. 2053, pl. 94,6d. \\
\hline TN 666 & LXII 43/26 XV a13.37 R210 & simple glass bead & hor. 16 a3 & Rahmstorf 2008, cat. no. 1950, pl. 84,24 \\
\hline TN 684 & LXII 43/31 XVIa c13.44 & simple glass bead & hor. 16 a50 & Rahmstorf 2008, cat. no. 1963 \\
\hline TN 667 & LXII 43/84 XVII d13.48 & simple glass bead & hor. 16 a50 & Rahmstorf 2008, cat. no. 1940, pl. 84,14 \\
\hline TN 680 & LXII 43/83 XVII c13.46 & simple glass bead & hor. 16 a50 & Rahmstorf 2008, cat. no. 1957, pl. 84,31 \\
\hline TN 681 & LXII 43/95 XVIII c13.27 & simple glass bead & hor. 16 a3 & Rahmstorf 2008, cat. no. 1958, pl. 84,32 \\
\hline TN 683 & LXII 43/75 XVIII a13.33 & simple glass bead & hor. 16 a3 & Rahmstorf 2008, cat. no. 1960, pl. 84,34 \\
\hline TN 686 & LXII 43/83 XVII a13.47 & simple glass bead & hor. 16 a50 & Rahmstorf 2008, cat. no. 1965 \\
\hline TN 905 & LXII 43/94 XVIII a13.27 & simple glass bead & hor. 16 a3 & Rahmstorf 2008, cat. no. 1944, pl. 84,18 \\
\hline TN 906 & LXII 43/83 XVII b13.45 & simple glass bead & & Rahmstorf 2008, cat. no. 1952, pl. 84,26 \\
\hline TN 1044 & LXII 43/51 XXIb a13.34 & ingot & hor. 16 a3 & $\begin{array}{l}\text { Archaeological Museum Nauplio, inv. no. 32441; } \\
\text { Rahmstorf 2008, cat. no. 2208, 270-271; Kilian } \\
\text { 1988, 130, fig. 37,4 }\end{array}$ \\
\hline TN 710 & LXII 43/46 XVIa a13.20 R210 & lead clamp & hor. 16 a1 & \\
\hline TN 740 & LXII 43/12 XVII a12.95 R214 & lead scrap & hor. 16 a1 & \\
\hline TN 748 & LXII 43/42 XVIb a13.19 & $\begin{array}{l}\text { lead sheet, prob. frag- } \\
\text { ment from lead vessel }\end{array}$ & hor. 16 a3 & \\
\hline TN 726 & LXII 43/85 XVII a13.30 & lead clamp & hor. 16 a50 & \\
\hline TN 762 & LXII 43/47 XIV a13.49 R210 & scrap bronze & hor. 16 a4 & Rahmstorf 2008, cat. no. 323 \\
\hline TN 786 & LXII 43/47 XV b13.42 & slag & hor. 16 a3 & Rahmstorf 2008, cat. no. 1769 \\
\hline TN 785 & LXII 43/33 XVIa R215 & slag & hor. 16 a4 & Rahmstorf 2008, cat. no. 1782 \\
\hline
\end{tabular}

alize specific finds that lend themselves to the discussion of exotica in three Late Bronze Age palatial areas (Fig. 2): two subsequent building horizons of a LH IIIB Middle context (case study 1A and 1B); LH IIIB Developed/Final deposits in Room 10 of Building Complex A (case study 2); the LH IIIB Early/Middle levels in the North of the Lower Citadel and the superimposed remains of the LH IIIB Final Building XI (case study $3 \mathrm{~A}$ and $3 \mathrm{~B}){ }^{63}$

1A. In a LH IIIB Middle terrace house ${ }^{64}$ from the mid-13th century BC (Fig. 3), several finds and features ${ }^{65}$ that indicate craft activities and/or a non-local origin of an object or its material components were revealed in its first building phase (stratigraphic horizons 16 a-16 a50; see Table 3 for non-local

63 For the absolute chronology of the palatial period see Shelmerdine 2001, 331-333 tab. 1; for the system of stratigraphic horizons in the Lower Citadel see Kilian 1988, 132 fig. 27; Rahmstorf 2008, 14; French \& Stockhammer 2008, 183, tab. 4 with slightly different terminology.

64 Kilian 1988, 130, 133-137, and fig. 36.

65 See also Rahmstorf 2008, 270-272, 287 pl. 133. items $\left.{ }^{66}\right)$. These are: a mould ${ }^{67}$ in Room 214 next to a fireplace; a lump of Egyptian blue near the mould; single glass beads in Rooms 210, 215 and several in the open area to the south; a bronze ingot hidden in the south wall of Room 215; lead scrap in Rooms 210, 214 and 215 and in the open area to the south; some bronze scrap and slag in Room $210^{68}$ and Room 215;

66 In the subsequent find list and Table 3 we do not refer to all finds excavated in this area and do not discuss stratigraphic issues, unless finds mentioned are difficult to assign either to the earlier or later occupation phase of the LH IIIB Middle building. Instead, we focus on the objects and installations that reveal information about activity areas and especially pyrotechnological processes due to constraints in time and space. However, all finds from these areas will be discussed in a forthcoming monograph.

67 TN 647 (+ TN $645+$ TN $646=$ joining fragments from later strata). TN stands for the relevant database number in the Tracing Networks: Cross-Craft Interaction in the Cross-Cultural Context of the Late Bronze Age Eastern Mediterranean/Tiryns database. Find spot TN 647: LXII 43/01 XVId R214, stratigraphic horizon 16 al; (find spot TN 646: LXIII 42/95 Vb, stratigraphic horizon 22; find spot TN 645: LXII 41/82 Xb, stratigraphic horizon 18); Kilian 1988, 137, 140 fig. 37,1; Rahmstorf 2008, 81 cat. no(s). (1789-) 1791, pls. 35,3, 90,9.

68 Both, scrap bronze and slag, were found close to the furnace in Room 210 


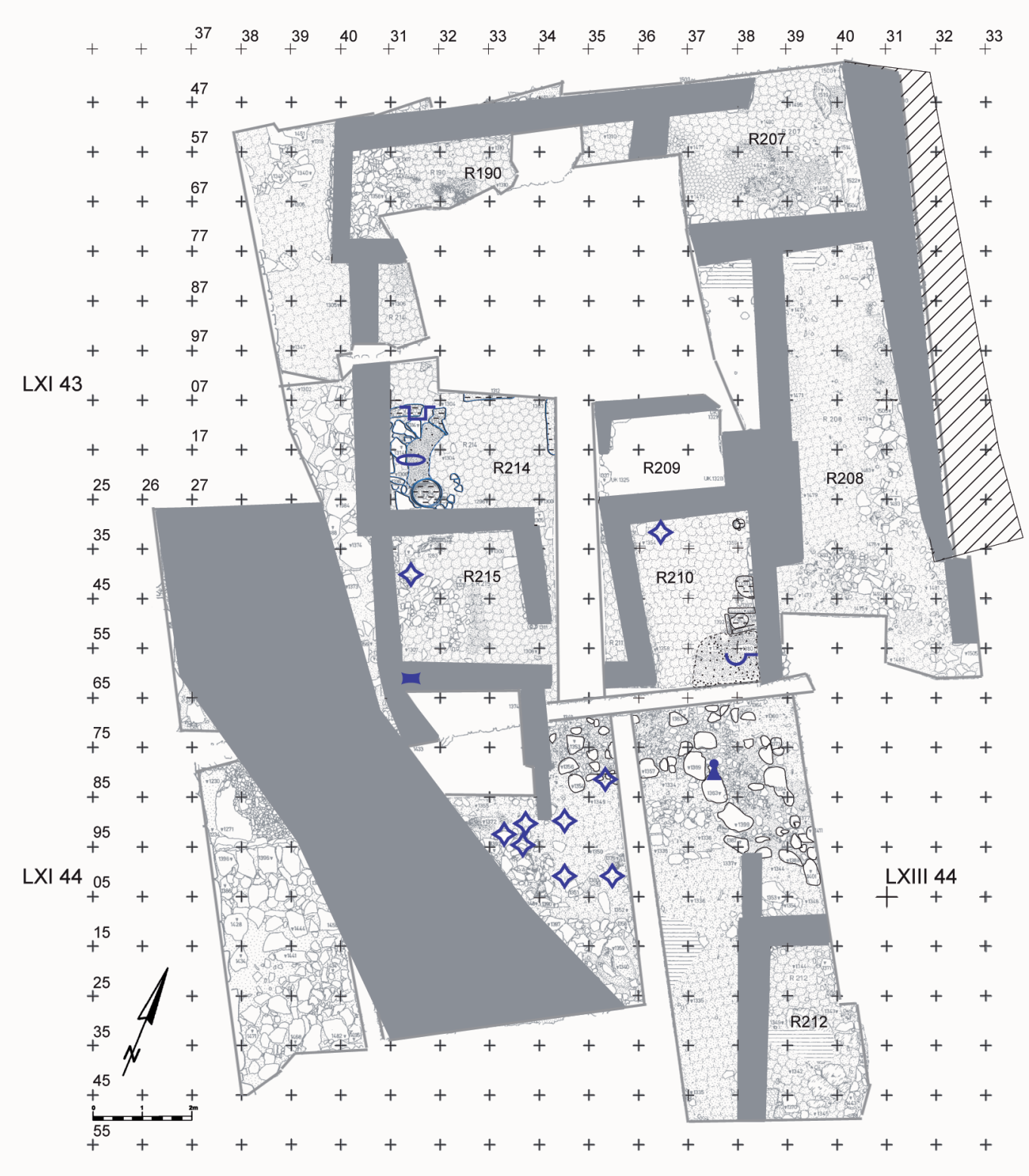

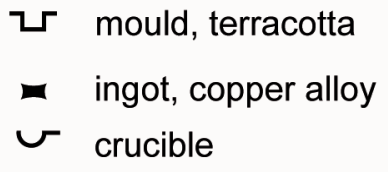
乙 mould, terracotta crucible

\section{- Egyptian blue \\ $\diamond$ simple bead, glass/faience \\ \& terracotta figure, wheelmade}

Fig. 3. Schematic plan of LH IIIB Middle complex with exotica and finds indicating metal working and ritual activities plotted, phase 1, hor. 16 a-16 a 50 . 
probably a furnace ${ }^{69}$ in Room 210; one crucible ${ }^{70}$ associated with that furnace in Room 210; an Aeginetan cooking pot, ${ }^{71}$ likely an installation for metallurgical activities, in Room 210; one grinding stone $\mathrm{e}^{72}$ nearby; two thirds of a wheelmade terracotta figure immediately south of Room $210 ;^{73}$ and half of a miniature cup in the north-east corner of Room $215 .^{74}$

The people, active in this building, must have conducted pyrotechnological activities that became visible to us in the production waste (slag), the mould and the crucible as well as such installations as the hearth in Room 214 and probably the furnace in Room 210. These remains thus allow us to identify Rooms 210, 214 and 215 as metallurgical workshops. In Room 214, where artisans may have been casting javelin heads, they likely discarded the mould fragment as refuse and the same probably holds true for the slag deposition in Room 210 where they were melting bronze. The Aeginetan cooking pot that was set into the floor of Room 210 forms a good example of the creativity with which artisans changed the function of objects when needed in a different setting. We believe that instead of functioning as a cooking pot, the vessel was probably used as a container for water and was thus integrated in the pyrotechnological activities carried out in this room. Moreover, although imported from the island of Aegina $^{75}$ and hence not a local product, the former cooking

69 TN $804=$ furnace Nr. 24 in Room 210; LXII $43 / 47$ Of. XIV a13.63 + LXII 43/48 a.13.97, hor. 16 a5-16 a7, Kilian 1988, 126, 135 fig. 31 . The furnace is not documented on the stone plan of the older occupation phase, see Kilian 1988, fig. 36 (after p. 138). However, the find of a crucible and slag nearby indicate that the furnace was probably already in use during horizons 16 al-16 a50, i.e. in the older occupation phase, see also Rahmstorf 2008, 271.

70 TN 648. Find spot: LXII 43/57 XIV R210 + LXII 43/58 a13.54 (two joining fragments), hor. 16 a4 + hor. 16 a50-16a 5; Kilian 1988, 126, 135 fig. 32; Rahmstorf 2008, 84-85 cat. no. 1809, pls. 37,5, 91,1. Again, Kilian only mentions the crucible in his description of the younger occupation phase. However, according to his unpublished stratigraphic tables the find falls squarely within his hor. 16 a4, which date is also followed by Rahmstorf 2008, 84 .

71 Aeginetan cooking pot MN 30804; LXII 43/28 Ofl. XVI a13.25 R210, hor. 16 a2; Kilian 1988, 126.

72 TN 776 is a limestone grinding stone; LXII 43/28 Ofl. XVI, hor. 16 a2.

73 TN 1197, find spot: LXII 43/77 Ofl. XVIII, hor. 16 a3 + LXI 44/28 IIc, unstratified + LXI 41/89 VIb, hor. 21 a0 + 71/208 III, unstratified; Vetters 2009, DB-Nos. $837+2083+2084+2085$; the broken figure was found on the surface of the alley immediately south of Room 210; the stem that approximately constitutes half of the figure is clearly stratified; two further, joining fragments of the torso came to light in later strata; Vetters 2011a, 39-41 figs. 2.2 bottom; 2.3.

74 TN 1094, find spot: LXII 43/33 XVIa R215, hor. 16 a4; Damm 1997, 297 M411, pl. 27 M411. Only the cited examples constitute well preserved miniature vessels. The area features numerous additional small sherds of miniature vessels and fragments of terracotta figurines that, however, do not provide evidence for primary deposition.

75 See Lindblom 2001, 41 for the export of Aeginetan cooking pots from the start of the Late Mycenaean period and the peak of Aeginetan pot also highlights that it probably did not retain a clearly foreign connotation in its secondary context, since such cooking pots were being imported for more than a century. Although people were probably aware of the fact that these pots were not produced in the Argolid, it seems that their common occurrence in Tiryns precludes a perception of such vessels as exotic. Instead, people probably valued them for their purely practical superior thermal properties.

In contrast to this, a closely intertwined web of both practical and symbolic activities is recognized in the hiding of a bronze ingot (weighing approximately $20 \mathrm{~kg}$ ) in the southern wall of Room 215, the presence of a large wheel-made figure immediately south of Room 210, likely set up in Room 210 to protect the pyrotechnological processes ${ }^{76}$ and the wellpreserved miniature cup in Room 215, once perhaps used for libations. It is also curious to find that most of the glass beads are scattered in the open area south of the building and are thus not closely associated to either the hearth in Room 214 or the furnace in Room 210 that constitute the main artisanal activity areas. However, these beads cannot be interpreted as the remains of a lost necklace, because, although they are spatially confined, they occur at different elevations. They may perhaps be interpreted as votive beads once associated with the large figure ${ }^{77}$ and thus also connecting symbolic aspects with production processes. Especially the bronze ingot, the Egyptian blue lump and the glass beads merit a closer look since they offer a good example of the context-dependency when we investigate what precisely constitutes the exotic character of these finds, and how the perception of their constituent materials/components may have changed in the course of their object biography.

Prior to making and bringing the bronze ingot to Tiryns, some artisans were mining and smelting ore elsewhere (or they recycled bronze scrap) since there is no evidence for ingot production at Tiryns. Since we assume that these first steps in the process of producing metal items, possibly javelin heads ${ }^{78}$ were carried out elsewhere, it is equally possible that the artisans, responsible for those first steps in this production process, may have been aware of a wide range of subsequent products that could evolve out of the ingots they initially produced.

Egyptian blue as a man-made pigment has been discussed at length by various specialists ${ }^{79}$ and without summarizing

pottery production in the Mycenaean period. From LH IIIB to LH IIIC Early, the export of Aeginetan pottery was limited to cooking pots, Lindblom 2001, 117.

76 Kilian 1992, 15; Vetters 2009, chapter V.3.3; 2011a, 39-41.

77 For the association of beads and figurines see Tzonou-Herbst 2002, 206-218.

78 Vetters \& Brysbaert forthcoming.

79 See e.g. Kakoulli 2009 for a recent but out of date overview on Greek Bronze Age Egyptian blue occurrences. 
this, suffice to state that this pigment may be named as the material-connecting-node in professional and possibly also social networks between glass workers, metal smiths (ku-wano-wo-ko-i and $k a-k e-w e$ as recorded in the Linear B-texts), painters and plasterers. The glass workers can produce the intense blue colour of the pigment by obtaining left-over copper bits from the smiths (too small or insignificant for their own production line). These recycled copper or bronze bits (see the Discussion section below) may subsequently gain in value again when mixed in with the glassy substance in producing the deep blue pigment. The pigment then links the glass makers to the wall painters, who would use the pigment in their paintings.

Allowing the bronze ingot and the Egyptian blue to be handled by their respective producers highlights that this case-study/phase consisted of partially worked materials that eventually would result in finished products. These materials are thus left-overs from which certain processes can be understood. These processes clearly crossed over but not just on a material level. It was by dissecting the finds in such a way that we came to realize that some characteristics of the exotica were represented, but not all. In the case of the bronze ingot, the initial materials were likely imported (traditionally labelled as exotic). Once such items arrived in the Tirynthian workshop, many subsequent activities may have been carried out in situ before the completed item was ready. The processes required to produce Egyptian blue prove even more complex (see the Discussion section below). Dissecting these finds illustrates both the physical/material and, most importantly, the human and social cross-overs and strategies that were at work in producing the items we study and the left-overs we have analysed, as well as their context-dependent value. While the tiny copper bits may have lost much of their value for the metal smiths, they may have regained crucial value for the glass makers who needed precisely this ingredient to make their beautiful deep blue pigment, a material most often employed on wall paintings of this period.

1B. In the next occupation phase ${ }^{80}$ (Fig. 4) people did not change the architectural layout of this building and more finds and features of interest were uncovered (stratigraphic horizons 16 a5-17 a0, see Table 4 for non-local items). These include three crucible fragments ${ }^{81}$ in the open space south

80 Kilian 1988, 126-133; Rahmstorf 2008, 272-273 pl. 134.

81 TN 649, find spot: LXII 43/84 XVI, hor. 16 a6-16 a7; Rahmstorf 2008, cat. no. 1808, pls. 37,3, 91,1; TN 650, find spot: LXII 43/66 XV grau b14.06, hor. 16 a6-16 a7; Rahmstorf 2008, cat. no. 1810, pls. 37,6, 91,1; TN 654, find spot: LXII 43/66 XIVa grau, hor. 17 a0; Rahmstorf 2008, cat. no. 1811, pl. 38,4. of Room 210; several fragments of burnt painted plaster ${ }^{82}$ found inside the furnace and an adjacent shallow clay-lined pit employed as a working surface in Room 210; lead scrap concentrations in several areas; bronze scrap and slag from Room $210^{83}$ and in the open space south of it; two locallymade wall bracket ${ }^{84}$ fragments south of Room 210, and one potentially Cypriot wall bracket fragment from the immediately superimposed levelling layer above the destruction level, probably a residual find; glass beads in several rooms and the open area to the south; a whetstone in Room $215 ;^{85}$ fragments of torch holders ${ }^{86}$ in Room 215 and an almost complete one in corridor Room 211 in the destruction debris and the superimposed layer; an ivory appliqué in the shape of a column in the destruction layer of Room 190, a burnt ivory chip west of the room and an ivory rosette in the same open area, but in the levelling layer above the destruction layer and thus not well stratified; a concentration of well-preserved animal and group figurines in Room 214 respectively Room $190^{87}$ and in the same area a large fragment of a miniature cup; $;^{88}$ and a Canaanite amphora fragment, a so-called lead model of a

82 Due to problems in the stratigraphic sequencing of the furnace TN 804 (see above), it cannot be established with certainty that the plaster fragments belong to the second use phase in Room 210. However, following Kilian's description, it seems more prudent to assign them to horizons 16 a5-16 a7 than to the earlier occupation phase, i.e. horizons 16 a316 a 4 .

83 The same stratigraphic problem already mentioned in the case of the burnt plaster fragments associated with the furnace holds true for the bronze scrap as well.

84 On wall brackets in general see Panitz-Cohen 2006; Rahmstorf $2008,91-111$. The most common interpretation of these objects to date is that they may have served as lamps or incense burners.

85 TN 706, find spot: LXII 43/33 XVc, hor. 16 a7-17 a0; Rahmstorf 2008 , cat. no. 1258 , pls. $69,17,94,4$.

86 On torch holders see Kilian 1986; Rahmstorf 2008, 111-121.

87 TN 1113, find spot: LXII 42/71 XIVa a13.49 R214, hor. 16 a7 + LXI 42/69 XIVa, hor. 16 a7 + LXII 42/71 a13.53, hor. 16 a7; Vetters 2009, DB-Nos. 653 + 2005 + 2006; TN 1114, find spot: LXII 42/71 XIVa b13.49, hor. 16 a7; Vetters 2009, DB-No. 654; TN 1115, find spot: LXII 42/71 XIVa c13.51 R214, hor. 16 a5; Vetters 2009, DB-No. 655; TN 1117, find spot: LXII 42/61 XV a13.42 R190, hor. 16 a5-16 a7; Vetters 2009, DB-No. 657; TN 1118, find spot: LXI $42 / 72$ XV a13.42 R190, hor. 16 a7 + LXI 42/70 XVI, hor. 16 a7; Vetters 2009, DB-Nos. $658+1208$; Vetters 2009, chapter V.3.3; 2012, 35.

88 TN 1049, find spot: LXII 42/57 XII + LXII 42/59 XII, hor. 16 a7-17 a0; Damm 1997, 293 M376, pl. 25 M376. A completely preserved miniature cup was found in the open area south of Room 210: TN 1047, find spot: LXII 43/95 XVI, hor. 16 a6; Damm 1997, 296 M404, pl. 27 M404. Another well-preserved miniature cup was probably also deposited in the open area, although its joining sherds are much more widely spread: TN 1048, find spot: LXII 43/96 XV grau, hor. 16 a6-16a7 + LXII 44/06 XVIIb (hor. 16 a4 and younger, disturbed area) + LXII 44/28 XIVa grau, hor. 16 a6-16 a 7 + LXII 44/19 XII, hor. 17 a0-19 b0 + LXI 42/90 X, hor. 17 a0; Damm 1997, 288 M323, pl. 21 M323. There are numerous additional smaller figurine fragments and sherds of miniature vessels that are not evaluated here, because it seems most probable that due to their extent of preservation they have been redeposited and 


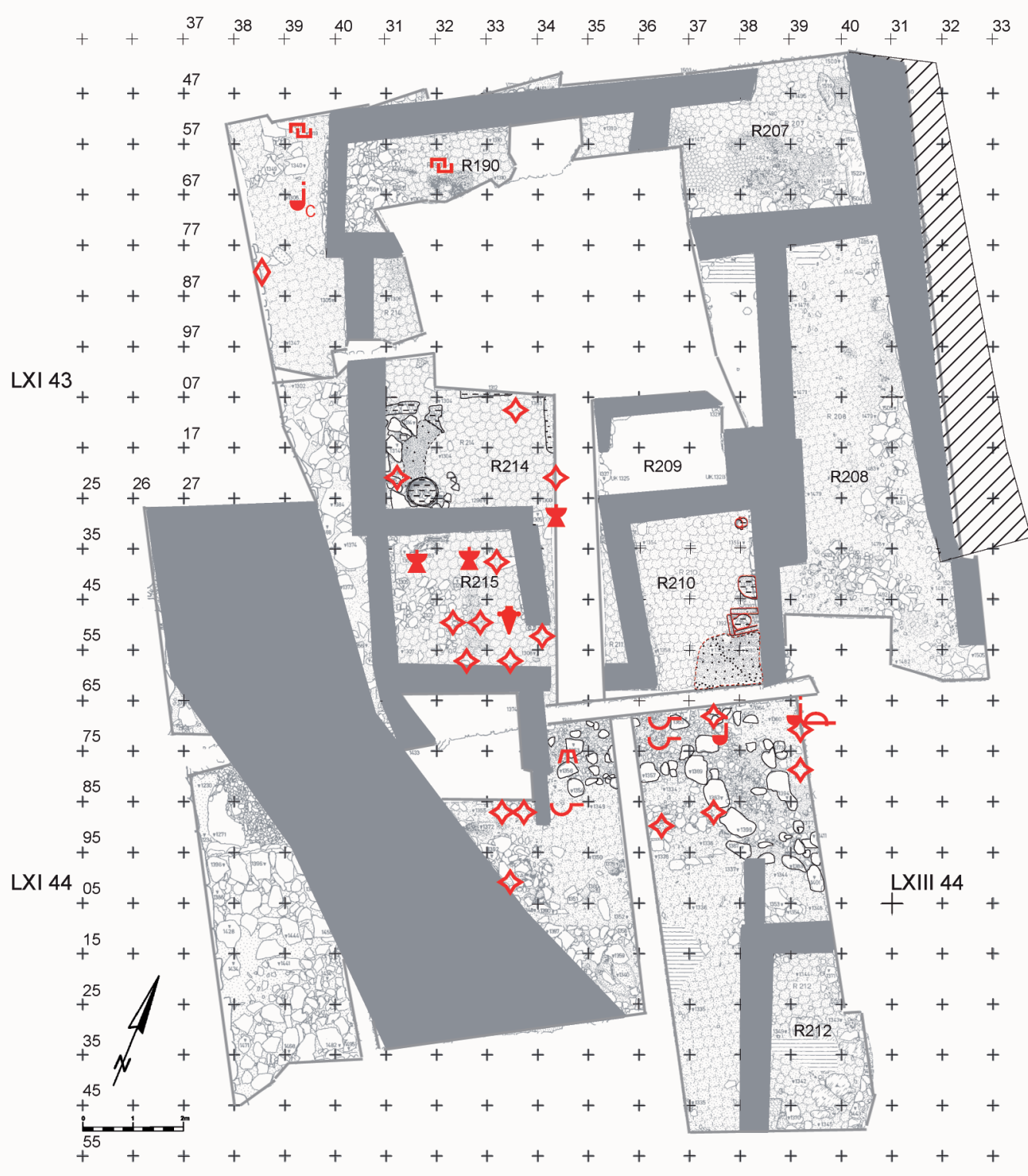

Fig. 4. Schematic plan of LH IIIB Middle complex with exotica finds plotted, phase 2, hor. 16 a5$17 a 0$.

\author{
$\checkmark$ crucible \\ j wall bracket \\ $j_{C} \quad$ wall bracket, 'Cypriote' \\ z torch holder \\ $\checkmark$ Canaanite amphora
}

a fibula

m tripod leg, lead

७ inlay/appliqué, ivory

$\diamond \quad$ varia, ivory 
Table 4. Lower Citadel Southwest, case study $1 B$-non-local materials or components in the LH IIIB Middle terrace house during the second occupation phase (stratigraphic horizons 16 a5-17 a0).

\begin{tabular}{|c|c|c|c|c|}
\hline$T N$-number & Find spot & Description & Stratigraphic horizon & Bibliography \\
\hline TN 795 & $\begin{array}{l}\text { LXII } 43 / 47 \text { b13.70 Nr. } 24 \\
\text { R210 }\end{array}$ & $\begin{array}{l}\text { painted plaster frag- } \\
\text { ment }\end{array}$ & hor. 16 a3-16 a 7 & \\
\hline TN 797 & $\begin{array}{l}\text { LXII } 43 / 48 \text { XV a13.62 Nr. } 24 \\
\text { R210 }\end{array}$ & $\begin{array}{l}\text { painted plaster frag- } \\
\text { ment }\end{array}$ & hor. 16 a3-16 a7 & \\
\hline TN 798 & $\begin{array}{l}\text { LXII } 43 / 48 \text { XV a13.62 Nr. } 24 \\
\text { R210 }\end{array}$ & $\begin{array}{l}\text { painted plaster frag- } \\
\text { ment }\end{array}$ & hor. 16 a3-16a7 & \\
\hline TN 962 & LXII 43/58 XIV Nr. 24 R210 & $\begin{array}{l}\text { painted plaster frag- } \\
\text { ment }\end{array}$ & hor. 16 a4-16 a7 & \\
\hline TN 972 & $\begin{array}{l}\text { LXII } 43 / 48 \text { XV a13.62 Nr. } 24 \\
\text { R210 }\end{array}$ & $\begin{array}{l}\text { painted plaster frag- } \\
\text { ment }\end{array}$ & hor. 16 a3-16 a7 & \\
\hline TN 719 & LXII 43/03 XVe a13.67 & lead lump & hor. 16 a6-16a7 & \\
\hline TN 736 & LXII 43/22 XV a14.06 & lead spill & hor. $17 \mathrm{a} 0$ & \\
\hline TN 750 & LXII 43/23 XVf a13.56 & lead lump & hor. 16 a6-16 a7 & \\
\hline TN 730 & LXII 43/36 XIII a13.83 R210 & lead clamp & hor. 17 a0 & \\
\hline TN 727 & LXII 43/95 XVI a13.61 & lead strip & hor. $16 \mathrm{a} 6-16 \mathrm{a} 7$ & \\
\hline TN 729 & LXII $43 / 85$ XV grau a 14.04 & lead casting residue? & hor. $16 \mathrm{a} 7-17 \mathrm{a} 0$ & \\
\hline TN 742 & LXII 43/94 XVI a13.59 & lead spill & hor. 16 a6-16a7 & \\
\hline TN 749 & LXII $43 / 83 \mathrm{XV}$ & lead clamp or sheet? & hor. $17 \mathrm{a} 0$ & \\
\hline TN 687 & LXII 43/47 Nr. 24 R210 & bronze scrap & hor. 16 a3-16a7 & Rahmstorf 2008, cat. no. 304; Kilian 1988, 126 \\
\hline TN 761 & LXII 43/46 XIIIa a13.61 R210 & bronze scrap & hor. 16 a7 & Rahmstorf 2008, cat. no. 320 \\
\hline TN 823 & $\begin{array}{l}\text { LXII 43/47 XIIIa a13.61 Nr. } \\
\text { 24 R210 }\end{array}$ & bronze hook & hor. 16 a5-16 a7 & Rahmstorf 2008, cat. no. 443 \\
\hline TN 764 & $\begin{array}{l}\text { LXII 43/48 XV b13.62 Nr. } 24 \\
\text { R210 }\end{array}$ & slag & hor. 16 a3-16 a7 & Rahmstorf 2008, cat. no. 332 \\
\hline TN 787 & LXII 43/47 XV a13.42 & slag & hor. 16 a3-16 a7 & Rahmstorf 2008, cat. no. 1778 \\
\hline TN 828 & $\begin{array}{l}\text { LXII 43/48 XV c13.62 Nr. } 24 \\
\text { R210 }\end{array}$ & slag & hor. 16 a3-16 a7 & Rahmstorf 2008, cat. no. 1779 \\
\hline TN 765 & $\begin{array}{l}\text { LXII } 43 / 58 \text { XIV a13.55 Nr. } \\
24 \text { R210 }\end{array}$ & slag & hor. 16 a5-16 a7 & Rahmstorf 2008, cat. no. 327 \\
\hline TN 756 & LXII 43/76 XV grau b14.00 & bronze wire & hor. $16 \mathrm{a} 7-17 \mathrm{a} 0$ & Rahmstorf 2008, cat. no. 446 \\
\hline TN 757 & LXII 43/84 XV a14.17 & bronze wire & hor. $16 \mathrm{a} 7-17 \mathrm{a} 0$ & Rahmstorf 2008, cat. no. 447 \\
\hline TN 759 & LXII 43/76 XV grau a14.00 & bronze scrap & hor. $16 \mathrm{a} 7-17 \mathrm{a} 0$ & Rahmstorf 2008, cat. no. 444 \\
\hline TN 760 & LXII 43/88 XVagrau a14.01 & bronze scrap & hor. $16 \mathrm{a} 7-17 \mathrm{a} 0$ & Rahmstorf 2008, cat. no. 441 \\
\hline TN 763 & LXII 43/89 XVI a13.86 & bronze scrap & hor. 16 a7 & Rahmstorf 2008, cat. no. 326 \\
\hline TN 643 & LXII 43/67 XV & wall bracket fragment & hor. $16 \mathrm{a} 7-17 \mathrm{a} 0$ & Rahmstorf 2008, cat. no. 1821 , pls. $39,4 \& 91,2$ \\
\hline TN 644 & LXII 43/69 XV & wall bracket fragment & hor. 16 a $7-17$ a 0 & $\begin{array}{l}\text { Rahmstorf 2008, cat. no. } 1828 \text {, pls. } 41,4 \& 91,4 \text {; } \\
\text { Kilian } 1988,128 \text {, fig. } 24,4\end{array}$ \\
\hline TN 708 & $\begin{array}{l}\text { LXI } 42 / 59 \text { XI c14.15 + LXI } \\
\text { 42/69 XII }\end{array}$ & $\begin{array}{l}2 \text { joining wall bracket } \\
\text { fragments }\end{array}$ & hor. $17 \mathrm{a} 0$ & $\begin{array}{l}\text { Rahmstorf 2008, cat. no. } 1829 \text {, pls. } 40,1 \& 91,3 \text {; } \\
\text { Kilian } 1988,128 \text {, fig. } 24,6\end{array}$ \\
\hline TN 788 & LXII 43/03 XVg a 13.50 & simple glass bead & hor. 16 a7 & Rahmstorf 2008, cat. no. 1935 , pl. 84,9 \\
\hline TN 789 & LXII 43/11 XV b14.10 & simple glass bead & hor. $17 \mathrm{a} 0-19 \mathrm{~b} 0$ & Rahmstorf 2008, cat. no. 1938, pl. 84,12 \\
\hline TN 904 & LXII 43/14 XIVa a14.14 & simple glass bead & hor. $17 \mathrm{a} 0$ & Rahmstorf 2008 , cat. no. 1948 , pl. 84,22 \\
\hline TN 664 & LXII 43/53 XVe a13.75 & simple glass bead & hor. 16 a7 & Rahmstorf 2008, cat. no.1946, pl. 84,20 \\
\hline TN 665 & LXII 43/42 XVf a13.62 & simple glass bead & hor. 16 a7 & Rahmstorf 2008, cat. no. 1937, pl. 84,11 \\
\hline TN 678 & LXII 43/44 XVc a13.90 & simple glass bead & hor. $16 \mathrm{a} 7-17 \mathrm{a} 0$ & Rahmstorf 2008, cat. no. 1955 , pl. 84,29 \\
\hline TN 790 & LXII 43/52 XVb a13.98 & simple glass bead & hor. 17 a0 & Rahmstorf 2008, cat. no. 1939, pl. 84, 13 \\
\hline TN 791 & LXII 43/42 XVb a13.97 & simple glass bead & hor. 17 a0 & Rahmstorf 2008, cat. no. 1941, pl. 84,15 \\
\hline TN 912 & LXII 43/33 XV a14.09 & simple glass bead & hor. $17 \mathrm{a} 0$ & Rahmstorf 2008, cat. no. 1942 , pl. 84,16 \\
\hline TN 663 & LXII 43/83 XVI c13.54 & simple glass bead & hor. 16 a6-16 a7 & Rahmstorf 2008 , cat. no. 1943 , pl. 84,17 \\
\hline TN 676 & LXII 43/67 XV grau b14.04 & simple glass bead & hor. $16 \mathrm{a} 7-17 \mathrm{a} 0$ & Rahmstorf 2008, cat. no. 1951 , pl. 84,25 \\
\hline TN 677 & LXII 43/79 XVII a13.68 & simple glass bead & hor. 16 a5 & Rahmstorf 2008, cat. no. 1954, pl. 84,28 \\
\hline
\end{tabular}




\begin{tabular}{|c|c|c|c|c|}
\hline TN 679 & LXII 43/83 XVI a13.59 & simple glass bead & hor. 16 a5-16 a7 & Rahmstorf 2008, cat. no. 1956, pl. 84,30 \\
\hline TN 682 & LXII 43/87 XVIIIb a13.38 & simple glass bead & hor. 16 a5 & Rahmstorf 2008, cat. no. 1959 , pl. 84,33 \\
\hline TN 685 & LXII 43/93 XVII a 13.65 & simple glass bead & hor. 16 a5 & Rahmstorf 2008, cat. no. 1964 \\
\hline TN 792 & LXII 43/86 XIII a14.20 & simple glass bead & hor. $17 \mathrm{a} 0$ & Rahmstorf 2008, cat. no. 1962, pl. 84,36 \\
\hline TN 886 & LXII 43/69 XIII a14.32 & simple glass bead & hor. $17 \mathrm{a} 0$ & Rahmstorf 2008, cat. no. 1936 , pl. 84,10 \\
\hline TN 661 & LXII 43/32 XVf a13.57 & $\begin{array}{l}\text { fragment of torch } \\
\text { holder }\end{array}$ & hor. 16 a7 & $\begin{array}{l}\text { Rahmstorf 2008, cat. no. 2353, pls. } 42,3 \& 91,5 \text {; } \\
\text { Kilian } 1986,155 \text {, fig. } 1,8\end{array}$ \\
\hline TN 802 & LXII 43/31 XVf & $\begin{array}{l}\text { fragment of torch } \\
\text { holder }\end{array}$ & hor. 16 a7 & $\begin{array}{l}\text { Rahmstorf 2008, cat. no. 2375, pl. 45,10; Kilian } \\
\text { 1986, 158, fig. 2,30 }\end{array}$ \\
\hline TN 658 & LXII 43/24 XVb al4.14 & $\begin{array}{l}\text { fragment of torch } \\
\text { holder }\end{array}$ & hor. 16 a $7-17$ a 0 & $\begin{array}{l}\text { Rahmstorf 2008, cat. no. } 2365 \text { pls. 43,5, 91,6; Kilian } \\
\text { 1986, } 157 \text { fig. 2,20 }\end{array}$ \\
\hline TN 923 & LXII $42 / 52$ XIc a 13.66 & $\begin{array}{l}\text { ivory appliqué in the } \\
\text { shape of a column }\end{array}$ & hor. 16 a7 & $\begin{array}{l}\text { Krzyszkowska 2005, 204, cat. no. 18, pl. 2,18; Kilian } \\
\text { 1983, 300, fig. 24,1; } 311\end{array}$ \\
\hline TN 821 & LXI 42/78 XIV & burnt ivory chip & hor. 16 a7 & \\
\hline TN 956 & LXI $42 / 49$ X a 14.19 & $\begin{array}{l}\text { ivory plaque in the } \\
\text { shape of a rosette }\end{array}$ & hor. 17 a0-19 b0 & $\begin{array}{l}\text { Krzyszkowska 2005, 204, cat. no. 19, pls. 2,19 \& } \\
619\end{array}$ \\
\hline TN 775 & LXII 43/43 XIV & $\begin{array}{l}\text { fragmentary Canaanite } \\
\text { amphora }\end{array}$ & hor. 17 a0-19 b0 & Kilian 1988, 129, fig. 25,12 \\
\hline TN 829 & LXII 43/74 XIIIa a14.12 & $\begin{array}{l}\text { fragmentary lead } \\
\text { model for tripod leg }\end{array}$ & hor. 17 a0-19 b0 & $\begin{array}{l}\text { Kilian 1983, 299, fig. 22,2, 307-308; Kilian 1984, } \\
\text { 56-57, 72, fig. } 2 \text { (right) }\end{array}$ \\
\hline TN 827 & LXII 43/69 Ofl. XIVa a13.96 & $\begin{array}{l}\text { bronze violin bow } \\
\text { fibula }\end{array}$ & hor. $17 \mathrm{a} 0$ & $\begin{array}{l}\text { Kilian } 1985,149,164 \text {, fig. 2, VA1; Rahmstorf } 2008 \text {, } \\
\text { cat. no. } 688\end{array}$ \\
\hline
\end{tabular}

miniature tripod leg and a violin bow fibula in the layer above the destruction layer. ${ }^{89}$

That metal smiths continued to use this space as a metallurgical workshop can be derived from the fact that crucibles, the furnace and the bronze scrap were left behind in Room 210. In contrast, ivory carvers cannot be identified based on the ivory fragments found in Room 190 and immediately west of it. Despite their Mycenaean motifs they were likely not crafted in these premises because no production waste was found. However, they are spatially associated with another probably imported item, the "Cypriot" wall bracket. Glass beads are concentrated in Room 215 and again in the open area south of the building. Since the central hole of a simple

thus only provide very indirect evidence for ritual practices connected to artisanal activities in this area.

89 Traditionally, the amphora, the tripod leg and the fibula have not been associated with the LH IIIB Middle building but just been vaguely ascribed to the debris layer that formed above the building and contained material from the end of the LH IIIB Middle phase to the LH IIIC Early phase. This material is not well stratified, since the subsequent open area does not feature distinct super-imposed floor or walking horizons on top of the LH IIIB Middle phase and is only sealed by architectural remains in the early post-palatial period. Thus, the finds mentioned have been widely dated between the LH IIIB Middle phase to the beginning of the LH IIIC period. However, the concentration of these non-local artefacts (two of them indicating Eastern Mediterranean influences-once an actual import, once an imitation of a type so far only known from $\mathrm{Cy}$ prus-one probably originating in the Western Mediterranean), fit well into the picture of international contacts (as evidenced by the import of the bronze ingot) of people working in the LH IIIB Middle building, although the items have come to light in a layer above the actual building. bead found in Room 215 was not completely pierced through, this example may have constituted a waste product, but any other wasters pointing to glass bead manufacture are missing. Handmade animal and oxcart-group figurines in the entrance area of Room 214/Room 190 contrast with the wheel made female figure in the previous phase and apparently represent a specific selection of types. Closely associated with the figurines is a miniature cup that may have formed a set along with the figurines, once used in ritual practices connected with the protection of the entrance as a liminal sphere..$^{90}$ As wall brackets were apparently also used in ritual rather than in purely utilitarian practices, ${ }^{91}$ it seems plausible that local and foreign ritual practices were amalgamated or carried out alongside one another in the building.

Also, in this second phase, several finds that were closely associated spatially, such as local wall brackets and the bronze violin-bow fibula, ${ }^{92}$ indicate that the artisans were familiar with items and practices that are very uncommon or even absent from other Mycenaean palatial workshops. Moreover, several items or their constitutive components were imported: glass beads and ivory fragments (raw material import), a Cypriot wall bracket (object made elsewhere and imported), a Canaanite amphora (object made elsewhere and imported),

\footnotetext{
90 Kilian 1988, 133; Kilian 1992, 14, 21; Vetters forthcoming.

91 Panitz-Cohen 2006.

92 Although an association of these exotica in their original use-context cannot be established, at least their final deposition just south of Room 210 may indicate that they were used or re-used in the metallurgical activities of that room.
} 


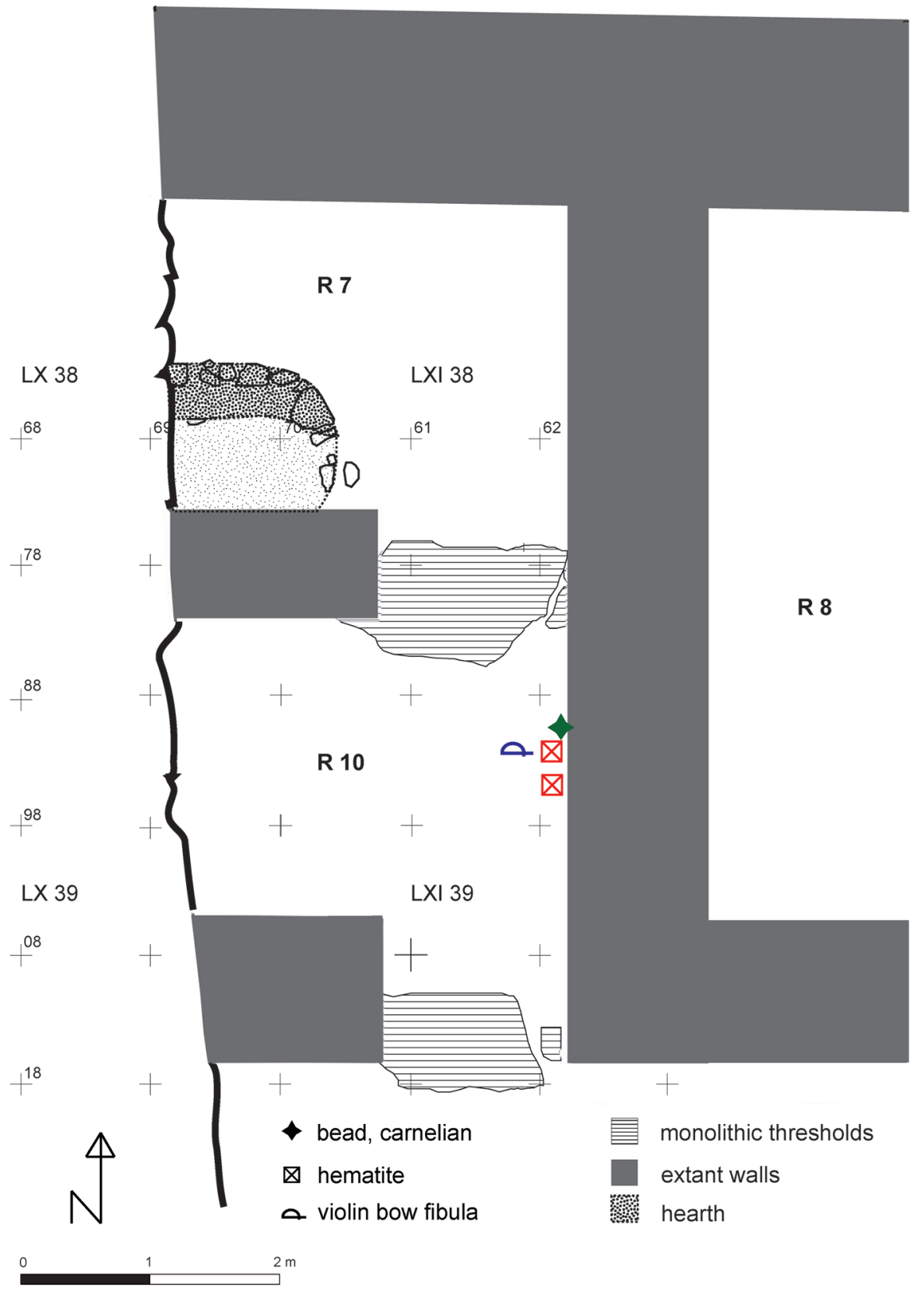

first floor/occupation phase (hor. 17 a1-17 a2)

- second floor/occupation phase (hor. 17 a3-17 a4)

third floor /occupation phase (hor. 17 a5-18) potentially the torch holders' contents $^{93}$ (material produced elsewhere and imported), the miniature lead tripod leg (raw material imported from elsewhere, but potentially modelled on site yet imitating a foreign object and design), and the bronze violin bow fibula (object probably made elsewhere and imported). The violin bow fibula, a type known mostly from Italy ${ }^{94}$ will be discussed in the project's final publication. Suffice to state that we have currently no evidence to suggest that this type of fibula was produced in Tiryns and was thus likely imported as a finished object. It is exactly the close spatial association and dense concentration of such items that suggest that these artisans were involved in or familiar with nonlocal practices while conducting their metallurgical activities.

2. Room 10 (Fig. 5) of Building I in Building Complex $\mathrm{A}^{95}$, situated north of the LH IIIB Middle Building in the Lower Citadel, dates to LH IIIB Developed/Final and overlaps with the occupation and activities of Building XI (see below, case study 3B). Materials of interest came to light on three occupation floors (see Table 5 for non-local materials). Within the LH IIIB Developed layer (stratigraphic horizon 17 a1-17 a2) were excavated three serpentinite conuli, a carnelian bead, three obsidian flakes, a bone spatula, a lump of lead (perhaps part of an ingot), a lead sheet, lead clamp fragments, a fragmentary bronze implement, perhaps part of a violin
Fig. 5. Schematic plan of LH IIIB Developed-Final Building Complex $A$ and Room 10 with exotica finds plotted (Tiryns-archive; with kind permission by Joseph Maran, our modification).
93 Rather than the torch-holders themselves. The residue preserved in one of them has been analysed in the early 1980 s as probably containing coniferous resin, see Kilian 1986, 165-166.

94 For Italian parallels see Kilian 1985, 162.

95 Kilian 1981, 175-177 with fig. 27, esp. 176, see also Rahmstorf 2008, 252-253, pls. 113-114. 
Table 5. Finds from Room 10 in Building Complex A in the western-central Lower Citadel during the phases LH IIIB Developed-Final (hor. 17 al-18).

\begin{tabular}{|c|c|c|c|c|}
\hline$T N$-number & Find spot & Description & Stratigraphic horizon & Bibliography \\
\hline TN 832 & LX 38/79 Xa & obsidian flake & hor. 17 a1 & \\
\hline TN 600 & LX 38/100 Xa a12.96 R10 & $\begin{array}{l}\text { lead lump, perhaps } \\
\text { part of an ingot? }\end{array}$ & hor. 17 al & \\
\hline TN 831 & LX 38/89Xb & obsidian blade & hor. 17 al & \\
\hline TN 830 & LX 38/89 Xc R10 & obsidian flake & hor. 17 a1 & \\
\hline TN 621 & LXI 38/81 X a13.04 & bone awl or spatula & hor. 17 a1 & Rahmstorf 2008 , cat. no. 1308 , pls. $74,6 \& 97,6$ \\
\hline TN 597 & LXI 38/81 Xa & lead clamp with sherd & hor. 17 al & \\
\hline TN 601 & LXI 38/81 Xa a 12.96 R10 & bronze, unidentified & hor. 17 al & Rahmstorf 2008, cat. no. 503 \\
\hline TN 616 & LX 38/89 X a13.03 R10 & Serpentinite conulus & hor. 17 a1-17 a2 & Rahmstorf 2008, cat. no. 13, pls. $47,36 \& 91,10$ \\
\hline TN 617 & LX 38/90 X R10 & Serpentinite conulus & hor. 17 a $1-17$ a2 & Rahmstorf 2008 , cat. no. 28 , pls. $51,8 \& 91,11$ \\
\hline TN 614 & LX 38/90 X a13.01 R10 & $\begin{array}{l}\text { fragmentary bronze } \\
\text { implement, perhaps } \\
\text { part of fibula }\end{array}$ & hor. 17 a1-17 a2 & Rahmstorf 2008, cat. no. 385 \\
\hline TN 595 & LX 38/90 X a13.02 R10 & lead sheet & hor. 17 a $1-17$ a2 & \\
\hline TN 613 & LX 38/90 X b13.09 R10 & bronze arrow bolt & hor. 17 a1-17 a2 & Rahmstorf 2008 , cat. no. 632 \\
\hline TN 594 & LXI 38/72 X a13.05 & lead clamp? & hor. 17 a1-17 a2 & \\
\hline TN 619 & LXI 38/81 X a13.00 R10 & Serpentinite conulus & hor. 17 a1-17 a2 & Rahmstorf 2008, cat. no. 56, pls. 51,40 \& 91,11 \\
\hline TN 620 & LXI 38/82 X a12.97 R10 & carnelian bead & hor. 17 a1-17 a2 & Rahmstorf 2008, cat. no. 2016, pl. 52,15 \\
\hline TN 624 & LX 38/80 IXf a13.14 R10 & marble spool & hor. 17 a3 & Rahmstorf 2008, cat. no. 1248 , pls. $68,2 \& 94,3$ \\
\hline TN 598 & LX 38/90 IXf a13.19 R10 & lead, prob. casting spill & hor. 17 a3 & \\
\hline TN 623 & LX 38/99 IXf a13.18 R10 & limestone mortar & hor. 17 a3 & Rahmstorf 2008, cat. no. 1257 , pls. $66,1 \& 94,1$ \\
\hline TN 622 & LX 38/99 Ofl. X R10 & clay pestle or stopper & hor. $17 \mathrm{a} 3$ & Rahmstorf 2008, cat. no. 2331. pls. $34,15 \& 97,2$ \\
\hline TN 618 & LXI 38/81 IXf a13.14 & spindle whorl of stone & hor. $17 \mathrm{a} 3$ & Rahmstorf 2008, cat. no. 239 , pls. $4,18 \& 89,4$ \\
\hline TN 642 & LXI 38/82 b13.13 R10 & haematite & hor. 17 a3 & Rahmstorf 2008, cat. no. 1764 \\
\hline TN 780 & LXI 38/82 IXf R10 & haematite & hor. 17 a3-17 a4 & \\
\hline TN 833 & LXI 38/82 IXf R10 & obsidian flake & hor. 17 a3-17 a4 & \\
\hline TN 615 & LXI 38/81 IXe a13.20 R10 & $\begin{array}{l}\text { fragmentary bronze } \\
\text { fibula }\end{array}$ & $\begin{array}{l}\text { hor. } 17 \text { a } 4 \text { or hor. } \\
17 \text { a } 5\end{array}$ & $\begin{array}{l}\text { Rahmstorf 2008, cat. nos. 383, 687; Kilian 1985, } \\
\text { 149, fig. 2, III B3, 152, } 162\end{array}$ \\
\hline TN 835 & LX 38/89 IXa & obsidian blade & hor. 18 & \\
\hline TN 834 & LX 38/90 IXc R10 & obsidian flake & hor. 18 & \\
\hline
\end{tabular}

bow fibula ${ }^{96}$ and another unidentified bronze fragment and a bronze arrow bolt as well as two well preserved handmade female terracotta figurines. ${ }^{97}$ Within the LH IIIB Developed layer (stratigraphic horizon 17 a3-17 a4) came to light a stone spindle whorl, a limestone mortar, a marble spool, ${ }^{98}$ lead casting residue, two haematite lumps, a clay pestle and four ter-

96 TN 614. If this wire fragment constitutes part of a fibula, then its diameter appears to be too small to constitute the missing part of fibula TN 615 from the same room and thus was probably not part of the latter. 97 TN 1219, find spot: LX 38/89 X b13.04 R10, hor. 17 a2; Vetters 2009, DB-No. 89; TN 1220, find spot: LX 38/99 Xa a12.92 R10, hor. 17 a1; Vetters 2009, DB-No. 90. Two other, very fragmentary female figurines, TN 1215, find spot: LXI 38/72 X R10, hor. 17 a2, Vetters 2009, DB-No. 2123 and TN 1214, find spot: LX 38/90 X R10, hor. 17 a2; Vetters 2009, DB-No. 1529, and the fragment of an animal figurine, TN 1226, find spot: LXI 38/81 X b13.00 R10, hor. 17 a2, Vetters 2009, DB-No. 1126, represent in all probability redeposited material, see Vetters 2009, map 6.

98 Originally of Early Helladic date, see Rahmstorf 2008, 253. racotta figurine fragments. ${ }^{99}$ Within the LH IIIB Final layer (stratigraphic horizon 17 a5-18) were found a bronze violin bow fibula ${ }^{100}$ as well as a fragmentary obsidian blade and flake and three almost complete female terracotta figurines. ${ }^{101}$

99 Due to their state of preservation and types, however, these do not constitute clear-cut evidence for ritual use in this specific room; Vetters 2009, map 7. Especially the finds of this phase and the ash layers led Kilian $(1981,176)$ to assign the room a possible small-scale metallurgical function.

100 TN 615. The stratigraphic assignment of this fibula is ambiguous; Rahmstorf 2008, 252 assigns it to horizon 17 a3-17 a4, which would fit Kilian's unpublished stratigraphic tables, where spit IXe corresponds to hor. 17 a4. Also, according to the find's elevation the fibula was found a few centimetres below the last palatial floor, i.e. in hor. 17 a 4. Kilian 1985, 162, however, states that the fibula was found "auf dem Fußboden der letzten Nutzungsphase des Baues vor der großen Erdbebenkatastrophe und ist daher an das Ende von SH III B 2 zu datieren". According to the latter, the fibula should be assigned to the floor of hor. 17 a5.

101 The figurines are all mended from two to three fragments: Vetters 2009, DB-No. 85 + DB-No. 1644; DB-No. 86 + DB-No. 87 + DB-No. 
Clear indications for supporting the use of Room 10 as a workshop are lacking, but this is based purely on the absence of fixed installations and rather ambiguous finds. ${ }^{102}$ There is, however, a large fireplace in the south-west corner of the neighbouring Room 7 to the north. Room 10 is a transit room, rather small and, as an interior room, appears not to have been very well aerated, but the copious ash found in the room indicates the use of fire. ${ }^{103}$ The room's assemblage is distinguished by an uncommonly high number of well-preserved female figurines that have been interpreted as evidence for the ritual protection of craft activities in this room. ${ }^{104}$ However, the reconstruction of specific artisanal practices in this room is ambiguous. Although the first floor assemblage contained the highest amount of metal objects, only the artefacts from the second floor actually provide evidence for raw materials (haematite), production waste (lead casting residue) and grinding or crushing tools (a mortar, a marble spool and a clay pestle). These finds potentially indicate craft activity and interlinked processes such as the grinding of small amounts of metalliferous pigments and the processing of (non-local) lead, two materials that may well have been derived from the same source since haematite is ubiquitous. ${ }^{105}$

The carnelian bead, the haematite and the violin bow fibula from Room 10 all have clear exotic characteristics. Though occurring on different floors, they all came to light within the same square metre, but are spatially separated from the wellpreserved female figurines. Thus, despite the room's small size people may have been involved in various activities. This can be deduced from the rather structured deposition of different materials and objects. If the interpretation of the room's assemblage as evidence for small-scale metallurgical activities is accepted (working mainly in lead and perhaps producing small amounts of pigments), the occurrence of at least one fibula, a dress implement that is otherwise exotic in palatial layers, would provide an interesting parallel to the LH IIIB Middle example. Whether these dress accessories are to be

2039; DB-No. 93 + DB-No. 747; Vetters 2009, map 8; Vetters forthcoming.

102 Kilian did not find a hearth or fireplace in this room, nor was one encountered in later excavations by the Greek Antiquity Service in the course of restoration works. Therefore, Rahmstorf 2008, 253 is cautious in identifying the room as a workshop area.

103 The ashy layers encountered by Kilian, especially in horizon 17 a317 a 4 or LH IIIB Developed, are accompanied by pottery which shows signs of such great heat exposure that some of it actually warped, Kilian 1981,176 , yet there are no sign of a larger conflagration, which suggests that the ash derived from human activity rather than a fire destruction.

104 Vetters 2009, chapter V.5.2; forthcoming.

105 Haematite was referred to as found and seen near several mine areas in the Laurion area by mineral collectors, see e.g. Wendel \& Markl 1999. We like to point out, however, that, without having had the chance to consult this reference, we have no certainty whether haematite was also collected or mined from these locations as early as the Late Bronze Age. tentatively connected to foreign artisans, remains an open question, especially since fibulae are commonly considered as a female dress implement, whereas metallurgical activities are traditionally seen as male-centred crafts. On the other hand, there is no need to assume that all activities within this room were strictly male-run. Pigment crushing and production may well have been in the hands of women and children too. ${ }^{106}$

Another (dress) accessory merits discussion as well: the miniscule carnelian bead found on the first floor. Carnelian as a material is not native to the Aegean but found in Egypt. It has been employed in the Aegean for seal stones since the Old Palace period in Crete. ${ }^{107}$ The bead itself does not appear to be finished as it shows clear saw marks, suggesting that the material was imported, either as a half-worked bead or, more likely, as a raw material. Artisans may have intended to shape it locally into a bead (but never achieved this) or may have used it as a half-finished bead in a necklace anyway. ${ }^{108}$ It is likely that the artisans did not conduct all the work on this bead in this specific room because its chaîne opératoire could not be entirely recovered there and no further beads, bead waste or other signs of bead production such as the necessary tools to shape them, were recovered during excavation.

$3 \mathrm{~A} \cdot{ }^{109} \mathrm{In}$ an open area with an oven ${ }^{110}$ situated in the north of the Lower Citadel, slightly below Building XI, ${ }^{111}$ dating to the earlier 13th century BC, thus chronologically corresponding partly to the LH IIIB Middle complex in the south-western part of the Lower Citadel, a small fragment of the first ostrich egg excavated in Tiryns was recognized ${ }^{112}$ and has obvious exotic connections (Fig. 6). It is difficult to determine which specific activities people there may have conducted in the open area since clear boundaries of activity areas are missing and its relation to an enclosed space to the north, probably a room, is obfuscated by later, superimposed structures. So far it appears that the oven was not used to process metal since finds specifically indicating metallurgical activities are absent. The oven and ash associated with it are under analysis and may provide clues to precise activities in the future.

\footnotetext{
106 Brysbaert 2008, 152, 169, 171.

107 Evely 2000, 153.

108 See e.g. Hughes-Brock 1999, 290 who comments on the fact that some beads may have come in already half-worked, heat treated for colour enhancement on carnelian and agate or crust removal on amber; also more recently Philipps 2012 on the topic of repair, recycling and reuse of specific materials relating to jewellery-making.

${ }_{109}$ In case study $3 \mathrm{~A}$ and $3 \mathrm{~B}$, figurines and miniature vessels were not included because they were too fragmentary to be considered as evidence for primary deposition close to their former place of use.

110 Mudbrick oven TN 18; find spot: LXIII 35/21 VIF-VI $\eta$ Nr. 46/03, hor. 15-16; Maran 2008, 39, fig. 3 .

111 Maran 2008, 38-39, fig. 3.

112 Brysbaert 2013
} 


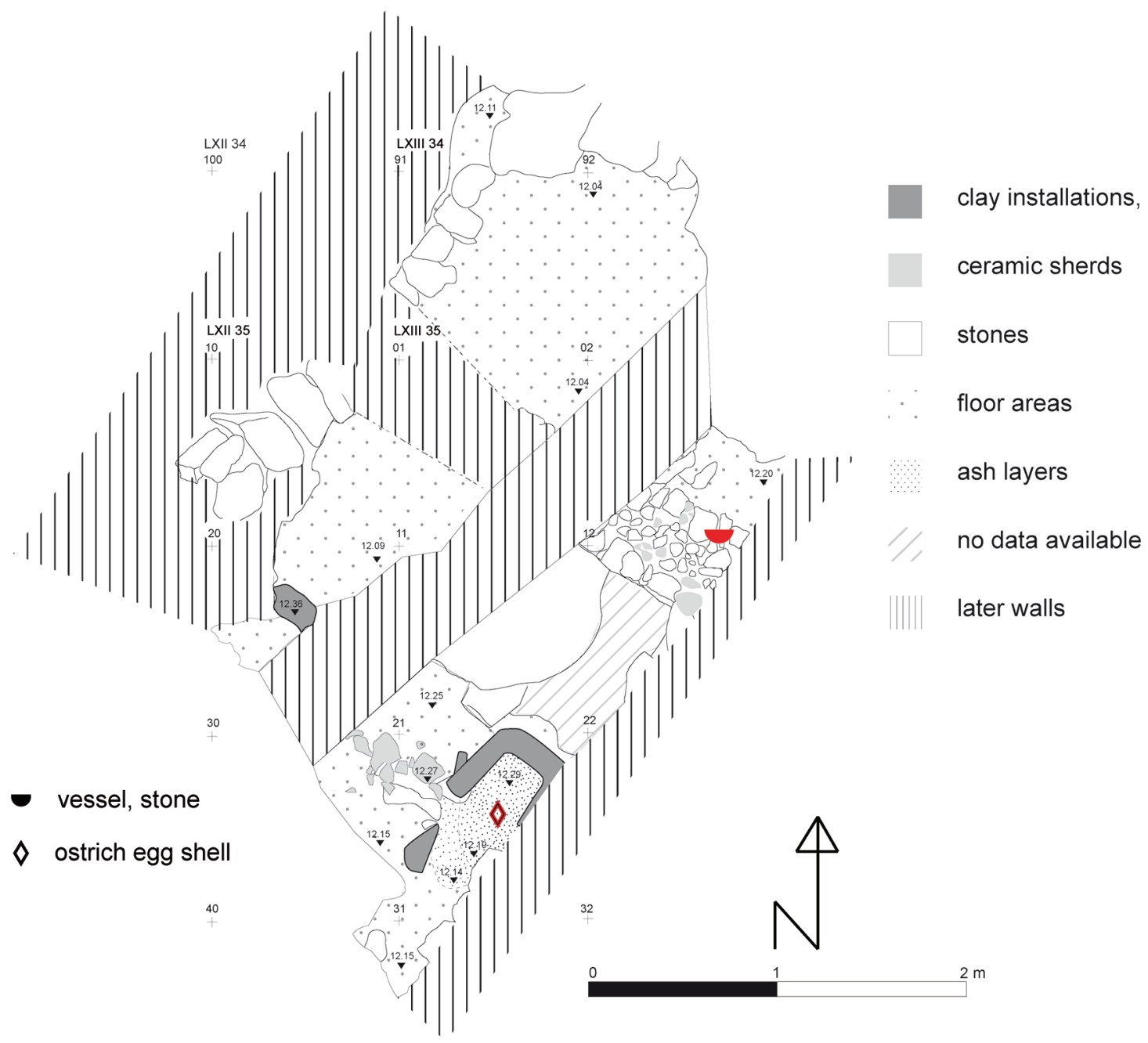

Fig. 6. Schematic plan of LH IIIB Early/Middle oven area with exotica finds plotted.

Finds in this area (see Table 6) were mainly obsidian blades and flakes, a chert flake, two radiolarite flakes or chips, a plaster fragment, two fragmentary circular modified sherds and an infant's tooth. In a pebble pavement or wall north of the oven a fragment of a stone vase was found, in secondary use as building material. Considering the find distributions in this area, the general image is of a common, domestic nature, despite the fragments of ostrich egg shell and of the stone vessel. Although the ostrich egg shell is burnt, its small size does not entirely preclude the possibility that it constitutes refuse stemming from its working or breakage elsewhere, since there are no further indications for the making of inlays in this area. However, the egg shell fragment need not have to be refuse of inlay making since it could also have been part of the fashioning of rhyta for which far less refuse would have been pro- duced. Possibly a similar scenario could be sketched for the stone vessel fragment because it was clearly found in secondary use. However, the finds do shed some valuable light on the changing status or appreciation of exotica: the ostrich egg has been discussed at length in relation to its chaine opératoire and its exotic nature elsewhere. ${ }^{113} \mathrm{In}$ sum, the ostrich egg itself was already worked and may have travelled for quite some time before it arrived in the Aegean. There, local specialized artisans may have finished it off with several other materials (faience appliqués, metal fixtures, gold foil, stone spouts ${ }^{114}$ ), either as

\footnotetext{
113 Brysbaert 2013, 250-252.

114 Several of these materials were certainly obtained from other artisans, indicating how such workers would have interacted again together to form the final outcome.
} 
Table 6. All moveable finds from the LH IIIB Early/Middle open area in the northern tip of the Lower Citadel.

\begin{tabular}{|c|c|c|c|c|}
\hline$T N$-number & Find spot & Description & Stratigraphic horizon & Bibliography \\
\hline TN 1 & LXIII 34/92 VIf & $\begin{array}{l}\text { fragmentary circular } \\
\text { modified sherd }\end{array}$ & hor. $15-16$ & \\
\hline TN 2 & LXIII 34/91 VIG a12.09 & $\begin{array}{l}\text { fragmentary obsidian } \\
\text { blade }\end{array}$ & hor. $15-16$ & \\
\hline TN 3 & LXIII 34/92 VIG a12.24 & $\begin{array}{l}\text { obsidian blade frag- } \\
\text { ment }\end{array}$ & hor. $15-16$ & \\
\hline TN 4 & LXIII 35/12 VIF a12.25 & obsidian flake & hor. $15-16$ & \\
\hline TN 5 & LXIII 35/01 VIG b12.15 & $\begin{array}{l}\text { fragmentary obsidian } \\
\text { blade }\end{array}$ & hor. $15-16$ & \\
\hline TN 6 & LXIII 35/12 VIF b12.25 & $\begin{array}{l}\text { obsidian, production } \\
\text { waste }\end{array}$ & hor. $15-16$ & \\
\hline TN7 & LXIII 35/12 VI $\eta$ a12.09 & $\begin{array}{l}\text { obsidian, fragmentary } \\
\text { crested blade }\end{array}$ & hor. $15-16$ & \\
\hline TN 8 & LXIII 35/21VIE b12.35 & $\begin{array}{l}\text { obsidian, preparation } \\
\text { flake }\end{array}$ & hor. $15-16$ & Brysbaert 2013 \\
\hline TN 10 & LXIII 35/21 VIn & $\begin{array}{l}\text { fragment of ostrich } \\
\text { egg shell }\end{array}$ & hor. $15-16$ & Brysbaert 2013 \\
\hline TN 11 & LXIII 35/12 VIF c12.26 & obsidian flake & hor. $15-16$ & \\
\hline TN 12 & LXIII 35/01 VIG a12.09 & obsidian flake & hor. $15-16$ & \\
\hline TN 13 & $\begin{array}{l}\text { LXIII 35/21 VIE c12.42 Nr. } \\
46 / 03\end{array}$ & obsidian flake & hor. $15-16$ & Brysbaert 2013 \\
\hline TN 14 & LXIII 35/21 VIE a12.34 & obsidian flake & hor. $15-16$ & Brysbaert 2013 \\
\hline TN 15 & LXIII 35/11 VIF c12.24 & chert flake & hor. $15-16$ & \\
\hline TN 16 & LXIII 35/02 VIG 12.22 & $\begin{array}{l}\text { obsidian, preparation } \\
\text { flake }\end{array}$ & hor. $15-16$ & \\
\hline TN 17 & LXIII 35/01 VIF a12.27 & $\begin{array}{l}\text { obsidian blade frag- } \\
\text { ment }\end{array}$ & hor. $15-16$ & \\
\hline TN 20 & LXIII 35/12 VIH a 12.20 & $\begin{array}{l}\text { obsidian blade frag- } \\
\text { ment }\end{array}$ & hor. $15-16$ & \\
\hline TN 23 & LXIII 35/21 VIF a12.26 & $\begin{array}{l}\text { premolar tooth of } \\
\text { infant }\end{array}$ & hor. $15-16$ & Brysbaert 2013 \\
\hline TN 53 & $\begin{array}{l}\text { LXIII 35/02 VIG unter } \\
\text { M10/02 Bst. 5/03 }\end{array}$ & obsidian flake & hor. $15-16$ & \\
\hline TN 54 & $\begin{array}{l}\text { LXIII 35/02 VIG unter } \\
\text { M10/02 Bst. 5/03 }\end{array}$ & obsidian flake & hor. $15-16$ & \\
\hline TN 55 & LXIII 35/02 VIG & obsidian flake & hor. $15-16$ & \\
\hline TN 874 & LXIII 35/11 VIF a12.25 & plaster fragment & hor. $15-16$ & \\
\hline TN 875 & $\begin{array}{l}\text { LXIII 35/02 VIH a12.24 Nr. } \\
59 / 03\end{array}$ & $\begin{array}{l}\text { fragmentary stone } \\
\text { vessel }\end{array}$ & hor. $15-16$ & \\
\hline TN 876 & LXII 35/40 VID a 12.40 & radiolarite chip & hor. $15-16$ & \\
\hline TN 877 & LXIII 35/11 VIF b12.24 & $\begin{array}{l}\text { fragmentary circular } \\
\text { modified sherd }\end{array}$ & hor. $15-16$ & \\
\hline TN 878 & LXII 34/100 VID b12.38 & $\begin{array}{l}\text { obsidian blade frag- } \\
\text { ment }\end{array}$ & hor. $15-16$ & \\
\hline TN 879 & LXII 35/30 VIF a 12.28 & radiolarite flake & hor. $15-16$ & \\
\hline TN 880 & LXIII 34/91 VIH a12.03 & obsidian flake & hor. $15-16$ & \\
\hline TN 881 & LXII 35/10 VIG a12.17 & obsidian flake & hor. $15-16$ & \\
\hline TN 882 & LXII 35/10 VIF a12.41 & obsidian flake & hor. $15-16$ & \\
\hline TN 883 & LXII 35/20 VIF a12.34 & obsidian flake & hor. $15-16$ & \\
\hline TN 884 & LXII 34/90 VIF 12.14 & obsidian flake & hor. $15-16$ & \\
\hline
\end{tabular}


an ostrich egg rhyton, or maybe as an inlay piece. As such, it was suggested that several artisans, working some (great) distance apart, but likely having some knowledge of each other's work-related activities, formed the professional and social network in which the egg formed the material node between them. ${ }^{115}$ Another point worth mentioning here is the use of non-local obsidian tools that appear to be completely integrated into the local material culture $^{116}$ and were probably preferred over the locally available chert examples because of superior functional properties, but were evidently not used as status markers.

3B. Building $\mathrm{XI},{ }^{117}$ situated above the layer discussed in $3 \mathrm{~A}$, dates to the LH IIIB Final phase, i.e. just before the Mycenaean palatial collapse (Fig. 7). A range of finds and features were attested for this phase (see Table 7). Room $78 \mathrm{a}^{118}$ contained a fireplace with two well-preserved wall brackets on its southern side, faience vessel fragments, ${ }^{119}$ a relief bracket bead near the fireplace, an amber bead, a knob-shaped terracotta object with a gold foil tinsel adhering to it, another gold foil tinsel, copper alloy spills, an ivory rod with incised cuneiform signs, ${ }^{120}$ and five copper alloy tools and implements as well as an andesite grinding stone and

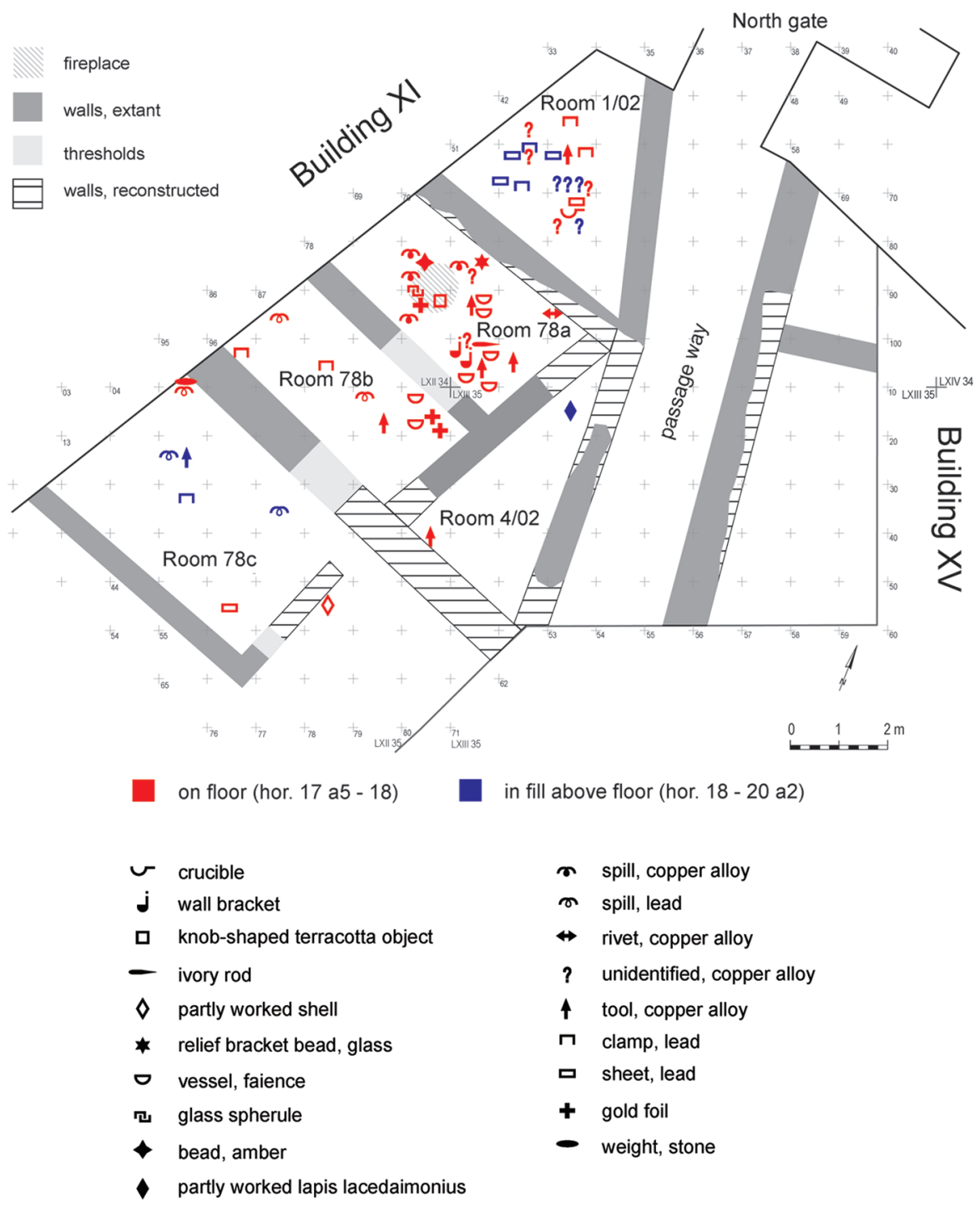

Fig. 7. Schematic plan of LH IIIB Final Building XI with exotica and finds indicating metal working or recycling plotted.

115 Brysbaert 2013, 250.

116 For the predominant use of obsidian in tool kits on all major sites in the Argolid since the Early Helladic period see Newhard 2003.

117 Maran 2008, 50-54; Brysbaert \& Vetters 2010, 29-31.

118 Several finds (TN 32, TN 33, TN 151, TN 179, TN 209) are difficult to assign stratigraphically to the floor assemblage, since their elevation would fall beneath the recorded floor levels of 12.80-12.86 metres above sea level (masl) (in the eastern part of the room) or rather in a pavement consisting of pebbles and small stones onto which the actual floor was built (between 12.85-12.94 masl in the western and 12.78-12.82 masl in the eastern part of Room 78a, see Maran 2008, 51).

119 For further details see Kostoula \& Maran 2012.

120 See in detail Cohen et al. 2010.

three obsidian blades. ${ }^{121}$ Room $78 \mathrm{~b}$ contained gold foil fragments, faience vessel sherds, three steatite conuli, ${ }^{122}$ and a bone button-shaped attachment with incised decoration. ${ }^{123}$ Room

121 Six obsidian flakes were found as well.

122 TN 47, find spot: LXII 34/99 IVa a12.90, hor. 17 a5, Rahmstorf 2008, 241, cat. no. 186, pl. 48,9; TN 48, find spot: LXII 34/100 IVb a12.81, hor. 17 a5, Rahmstorf 2008, 241, cat. no. 246, pl. 48,8); and an additional one from LXII 34/97 IV a12.98, hor. 17 a5, Rahmstorf 2008, 241, pl. 48,1.

123 TN 196, find spot: LXII 35/08 IV a12.96, hor. 17 a5; Krzyszkowska $2005,186,203$, no. 17, pl. 2,6. Furthermore, finds of non-local materials, i.e. several lead items as well as two obsidian flakes, and a copper alloy tool were found on the floor of Room 78b. Artefacts of local material 
Table 7. LH IIIB Final Building XI in the northern tip of the Lower Citadel; non-local finds.

${ }^{\mathrm{I}}$ I.e. made from non-local materials or in foreign or hybrid techniques.

\begin{tabular}{|c|c|c|c|c|}
\hline TN-number & Find spot & Description & Stratigraphic horizon & Bibliography \\
\hline TN 22 & $\begin{array}{l}\text { LXII 34/100 IVb + LXIII } \\
\text { 34/81 VI + LXIII 34/91 VI } \\
\text { a12.90 + LXIII 34/91 VI } \\
\text { + LXIII 35/01 VIA unter } \\
\text { Fußboden }\end{array}$ & wall bracket & hor. 17 a5 & $\begin{array}{l}\text { Maran 2004a, 4, 8, fig. 9; Maran 2008, 51, 52, fig. } \\
\text { 27; Kostoula \& Maran 2012, 195, } 216\end{array}$ \\
\hline TN 29 & $\begin{array}{l}\text { LXII 34/100 IVb + LXII } \\
\text { 35/10 IVb + LXII 35/19 IVb } \\
+ \text { LXIII 34/91 VI }\end{array}$ & wall bracket & hor. 17 a5 & Maran 2008, 51; Kostoula \& Maran 2012, 195, 216 \\
\hline TN 207 & LXIII 34/91 VI f12.81 & faience vessel fragment & hor. 17 a5 & Kostoula \& Maran 2012, 199, locus 2.4, figs. 4, 8 \\
\hline TN 208 & LXIII 34/91 VI g12.83 & faience vessel fragment & hor. 17 a5 & Kostoula \& Maran 2012, 199, locus 2.2-3, figs. 4, 8 \\
\hline TN 209 & LXIII 34/91 VIB c12.77 & faience vessel fragment & hor. 17 a4-17a5 & Kostoula \& Maran 2012, 199, locus 2.5, figs. 4, 8 \\
\hline TN 210 & LXIII 34/81 VIb c12.86 & faience vessel fragment & hor. 17 a5 & Kostoula \& Maran 2012, 200, locus 2.6, figs. 4, 8 \\
\hline TN 211 & LXIII 34/81 VIb b12.87 & faience vessel fragment & hor. 17 a5 & Kostoula \& Maran 2012, 200, locus 2.7, figs. 4, 8 \\
\hline TN 160 & LXIII 34/71 Ofl. VIA a12.86 & glass relief bead & hor. 17 a5 & Brysbaert \& Vetters 2010, 130, 141, tab. 1 \\
\hline TN 58 & LXII 34/80 IVb a12.80 & amber bead & hor. 17 a5 & Rahmstorf 2008, 241, cat. no. 2023, pl. 52,11 \\
\hline TN 57 & LXII 34/90 IVa a12.86 & $\begin{array}{l}\text { knob-shaped terracot- } \\
\text { ta object with gold foil } \\
\text { tinsel adhering to it }\end{array}$ & hor. 17 a5 & $\begin{array}{l}\text { Kilian 1984, 56, 71, fig. 3,9; Rahmstorf 2008, 241, } \\
\text { cat. no. 1786, pl. 35,10 }\end{array}$ \\
\hline TN 31 & LXII 34/90 IVb a12.84 & gold foil tinsel & hor. 17 a5 & Rahmstorf 2008, 241, cat. no. 1739 \\
\hline TN 56 & LXII 34/80 IVb a12.85 & $\begin{array}{l}\text { faience or glass } \\
\text { spherule }\end{array}$ & hor. 17 a5 & Rahmstorf 2008, 241, cat. no. 1916, pl. 85,51 \\
\hline TN 190 & LXIII 34/91 VI d12.80 & ivory rod & hor. 17 a5 & $\begin{array}{l}\text { Maran 2004a, 14, 25; Maran 2008, 52, fig. 29; } \\
\text { Cohen et al. } 2010\end{array}$ \\
\hline TN 32 & LXIII 34/91 VI e12.79 & copper alloy tool & hor. 17 a $4-17$ a5 & \\
\hline TN 33 & LXIII 34/92 VI a12.79 & copper alloy tool & hor. 17 a $4-17$ a5 & \\
\hline TN 38 & LXIII 34/91 VIB b12.77 & $\begin{array}{l}\text { copper alloy, corroded } \\
\text { sheet fragment }\end{array}$ & hor. 17 a5 & \\
\hline TN 70 & $\begin{array}{l}\text { LXIII 34/81 VIb e12.88 Profi- } \\
\text { labbau unter M 3/02 }\end{array}$ & copper alloy chisel & hor. 17 a5 & \\
\hline TN 74 & LXIII 34/83 VIA a12.93 & copper alloy rivet & hor. 17 a5 & \\
\hline TN 151 & LXIII 34/71 VIC a12.71 & $\begin{array}{l}\text { corroded amorphous } \\
\text { copper alloy fragment, } \\
\text { probably production } \\
\text { waste }\end{array}$ & hor. 17 a $4-17$ as & \\
\hline TN 152 & LXIII 34/71 VIC a12.71 & copper alloy spill & hor. 17 a5 & \\
\hline TN 781 & LXII 34/80 IVb a12.86 & copper alloy spill & hor. 17 a5 & Rahmstorf 2008,241 , cat. no. 1770 \\
\hline TN 782 & LXII 34/80 IVb a12.88 & copper alloy spill & hor. 17 a5 & Rahmstorf 2008, 241, cat. no. 1774 \\
\hline TN 783 & LXII 34/90 IVb a12.86 & copper alloy spill & hor. 17 a5 & Rahmstorf 2008, 241, cat. no. 1775 \\
\hline TN 19 & LXIII 34/91 VI c12.83 & $\begin{array}{l}\text { andesite grinding } \\
\text { stone }\end{array}$ & hor. 17 a5 & Maran 2008, 51 \\
\hline TN 43 & LXIII 34/81 VIa a12.80 & obsidian blade & hor. 17 a5 & Brysbaert \& Vetters 2010, 130, 141, tab. 1 \\
\hline TN 46 & LXIII 34/81 VI a12.90 & obsidian blade & hor. 17 a5 & Brysbaert \& Vetters 2010, 130, 141, tab. 1 \\
\hline TN 179 & LXIII 34/91 VIB f12.76 & obsidian blade & hor. 17 a $4-17$ a5 & \\
\hline TN 40 & LXIII 34/91 VIB & obsidian flake & hor. 17 a5 & \\
\hline TN 42 & LXIII 34/81 VI b12.86 & obsidian flake & hor. 17 a5 & \\
\hline TN 44 & LXIII 34/91 VI & obsidian flake & hor. 17 a5 & \\
\hline TN 150 & LXIII 34/82 Ofl. VIA b12.87 & obsidian flake & hor. 17 a5 & \\
\hline TN 164 & LXII 34/89 VIA a 12.82 & obsidian flake & hor. 17 a5 & \\
\hline TN 178 & LXII 34/69 VIC a 12.80 & obsidian flake & hor. 17 a5 & \\
\hline TN 35 & LXII 35/10 IVb a12.81 & gold foil tinsel & hor. 17 a5 & Rahmstorf 2008, 241, cat. no. 1741 \\
\hline
\end{tabular}




\begin{tabular}{|c|c|c|c|c|}
\hline TN 36 & LXII 35/10 IVb a12.80 & gold foil tinsel & hor. 17 a5 & Rahmstorf 2008, 241, cat. no. 1738 \\
\hline TN 204 & LXII 35/10 IVb & faience vessel fragment & hor. 17 as & $\begin{array}{l}\text { Kostoula \& Maran 2012, 200-201, locus 3.8, figs. } \\
\text { 5, 9; Rahmstorf 2008, 231, cat. no. 1839, pls. } 87,5 \\
\& 96,9\end{array}$ \\
\hline TN 205 & LXII 35/10 IVb & faience vessel fragment & hor. 17 a5 & $\begin{array}{l}\text { Kostoula \& Maran 2012, 201, locus 3.9, figs. 5, 9; } \\
\text { Rahmstorf 2008, 231, cat. no. 1840, pls. 87,4 \& 96,8 }\end{array}$ \\
\hline TN 49 & LXII 35/09 IVa a12.89 & copper alloy tool & hor. 17 a5 & Rahmstorf 2008, 241, cat. no. 357 \\
\hline TN 602 & LXII 34/98 IVb a12.84 & lead clamp & hor. 17 a5 & \\
\hline TN 606 & LXII 34/96 IVb a12.80 & lead clamp & hor. 17 a5 & \\
\hline TN 610 & LXII 34/87 IVb a12.72 & lead spill & hor. 17 a5 & \\
\hline TN 611 & LXII 34/95 IVb & lead spill & hor. 17 a5 & \\
\hline TN 612 & LXII 35/09 IV a12.97 & lead spill & hor. 17 a5 & \\
\hline TN 172 & LXIII 35/01 VI a12.85 & obsidian flake & hor. 17 a5 & \\
\hline TN 852 & LXII 34/99 IVb & obsidian flake & hor. 17 as & \\
\hline TN 223 & LXII 34/95 IV R78c & marble weight & hor. 17 a5 & $\begin{array}{l}\text { Rahmstorf } 2008,155,158,163 \text {, cat. no. } 1207, \text { pls. } \\
57,11 \& 93,1\end{array}$ \\
\hline TN 609 & LXII 35/46 a 12.80 & lead sheet & hor. 17 a5 & \\
\hline TN 192 & LXII 35/48 VI b12.85 & $\begin{array}{l}\text { partly worked shell } \\
\text { (prob. abalone) }\end{array}$ & hor. 17 a5 & \\
\hline TN 50 & LXII 35/15 IV a 12.93 & copper alloy chisel & hor. $18-20 \mathrm{a} 2$ & \\
\hline TN 604 & LXII 35/25 IV a12.92 & lead clamp & hor. $18-20$ a2 & \\
\hline TN 605 & LXII 35/27 IV a12.93 & lead spill & hor. $18-20 \mathrm{a} 2$ & \\
\hline TN 608 & LXII 35/15 IV a12.93 & lead spill & hor. $18-20 \mathrm{a} 2$ & \\
\hline TN 112 & LXIII 34/63 VIA b12.82 & obsidian flake & hor. 17 a5 & Brysbaert \& Vetters 2010, 41, tab. 2 \\
\hline TN 108 & LXIII 34/64 VIA a12.84 & obsidian blade & hor. 17 a5 & Brysbaert \& Vetters 2010, 41, tab. 2 \\
\hline TN 111 & LXIII 34/52 VIA b12.84 & obsidian flake & hor. 17 as & Brysbaert \& Vetters 2010, 41, tab. 2 \\
\hline TN 118 & LXIII 34/63 VIA a12.84 & obsidian flake & hor. 17 a5 & Brysbaert \& Vetters 2010, 41, tab. 2 \\
\hline TN 110 & LXIII 34/42 VIA a12.85 & obsidian flake & hor. 17 a5 & Brysbaert \& Vetters 2010, 41, tab. 2 \\
\hline TN 173 & LXIII 34/63 VI b12.85 & obsidian flake & hor. 17 a5 & Brysbaert \& Vetters 2010, 41, tab. 2 \\
\hline TN 107 & LXIII 34/54 VIA a12.85 & $\begin{array}{l}\text { obsidian, exhausted } \\
\text { core }\end{array}$ & hor. 17 a5 & Brysbaert \& Vetters 2010, 41, tab. 2 \\
\hline TN 114 & LXIII 34/52 VIA c12.90 & obsidian flake & hor. 17 a5-18 & Brysbaert \& Vetters 2010, 41, tab. 2 \\
\hline TN 117 & LXIII 34/33 VIA & obsidian flake & hor. 17 a $5-18$ & Brysbaert \& Vetters 2010, 41, tab. 2 \\
\hline TN 128 & LXIII 34/52 VI f12.92 & obsidian flake & hor. 17 a5-18 & Brysbaert \& Vetters 2010, 42, tab. 2 \\
\hline TN 98 & LXIII 34/62 VI a12.93 & obsidian blade & hor. 17 a 5-18 & Brysbaert \& Vetters 2010, 42, tab. 2 \\
\hline TN 121 & LXIII 34/43 VI a12.93 & obsidian blade & hor. 17 a5 & Brysbaert \& Vetters 2010, 42, tab. 2 \\
\hline TN 102 & LXIII 34/42 VI b12.94 & obsidian blade & hor. 17 a5- 18 & Brysbaert \& Vetters 2010, 42, tab. 2 \\
\hline TN 122 & LXIII 34/53 VI e12.94 & obsidian blade & hor. 17 a5-18 & Brysbaert \& Vetters 2010, 42, tab. 2 \\
\hline TN 123 & LXIII 34/52 VI d12.95 & obsidian blade & hor. 17 a5-18 & Brysbaert \& Vetters 2010, 42, tab. 2 \\
\hline TN 129 & LXIII 34/52 VI e12.96 & obsidian flake & hor. 17 a5-18 & Brysbaert \& Vetters 2010, 42, tab. 2 \\
\hline TN 126 & LXIII 34/42 VI a12.97 & obsidian blade & hor. 17 a5- 18 & Brysbaert \& Vetters 2010, 42, tab. 2 \\
\hline TN 130 & LXIII 34/53 VI a12.97 & obsidian flake & hor. 17 a5- 18 & Brysbaert \& Vetters 2010,42 , tab. 2 \\
\hline TN 131 & LXIII 34/52 VI a12.98 & obsidian flake & hor. 17 a5-18 & Brysbaert \& Vetters 2010, 42, tab. 2 \\
\hline TN 132 & LXIII 34/43 VI b 12.98 & obsidian flake & hor. 17 a5-18 & Brysbaert \& Vetters 2010, 42, tab. 2 \\
\hline TN 101 & LXIII 34/53 VI f12.99 & obsidian flake & hor. 17 a5-18 & Brysbaert \& Vetters 2010, 42, tab. 2 \\
\hline TN 104 & LXIII 34/52 VI b13.00 & obsidian blade & hor. $18-20$ a2 & Brysbaert \& Vetters 2010, 42, tab. 2 \\
\hline TN 105 & LXIII 34/43 VI & obsidian, burin & hor. $18-20 \mathrm{a} 2$ & Brysbaert \& Vetters 2010, 42, tab. 2 \\
\hline TN 125 & LXIII 34/63 VI & obsidian blade & hor. $18-20 \mathrm{a} 2$ & Brysbaert \& Vetters 2010, 42, tab. 2 \\
\hline TN 133 & LXIII 34/63 VI & obsidian flake & hor. $18-20 \mathrm{a} 2$ & Brysbaert \& Vetters 2010, 42, tab. 2 \\
\hline TN 138 & LXIII 34/63 VC f13.01 & obsidian flake & hor. $18-20$ a2 & Brysbaert \& Vetters 2010, 42, tab. 2 \\
\hline TN 137 & LXIII 34/42 VC a13.03 & obsidian blade & hor. $18-20 \mathrm{a} 2$ & Brysbaert \& Vetters 2010, 42, tab. 2 \\
\hline TN 139 & LXIII 34/64 VC a13.03 & obsidian blade & hor. $18-20 \mathrm{a} 2$ & Brysbaert \& Vetters 2010, 42, tab. 2 \\
\hline TN 124 & LXIII 34/63 VI c12.90 & obsidian micro-blade & hor. $18-20 \mathrm{a} 2$ & \\
\hline
\end{tabular}




\begin{tabular}{|c|c|c|c|c|}
\hline TN 96 & LXIII 34/52 VC g13.04 & obsidian blade & hor. $18-20 \mathrm{a} 2$ & Brysbaert \& Vetters 2010, 42, tab. 2 \\
\hline TN 141 & LXIII 34/52 VC b13.04 & obsidian flake & hor. $18-20 \mathrm{a} 2$ & Brysbaert \& Vetters 2010, 42, tab. 2 \\
\hline TN 135 & LXIII 34/63 VC e13.06 & obsidian blade & hor. $18-20$ a2 & Brysbaert \& Vetters 2010, 42, tab. 2 \\
\hline TN 140 & LXIII 34/63 VC d13.08 & obsidian flake & hor. $18-20 \mathrm{a} 2$ & Brysbaert \& Vetters 2010, 42, tab. 2 \\
\hline TN 97 & LXIII 34/63 VC & obsidian blade & hor. $18-20 \mathrm{a} 2$ & Brysbaert \& Vetters 2010, 42, tab. 2 \\
\hline TN 134 & LXIII 34/64 VC & obsidian blade & hor. $18-20 \mathrm{a} 2$ & Brysbaert \& Vetters 2010, 42, tab. 2 \\
\hline TN 167 & LXIII 34/63 VC c13.10 & obsidian blade & hor. $18-20 \mathrm{a} 2$ & \\
\hline TN 78 & LXIII 34/42 VIB a12.85 & $\begin{array}{l}\text { copper alloy } \\
\text { amorphous fragment }\end{array}$ & hor. 17 a5 & Brysbaert \& Vetters 2010, 42, tab. 3 \\
\hline TN 72 & LXIII 34/63 VI d12.90 & $\begin{array}{l}\text { copper alloy } \\
\text { amorphous fragment }\end{array}$ & hor. 17 a5-18 & Brysbaert \& Vetters 2010, 42, tab. 3 \\
\hline TN 88 & LXIII 34/52 VI c12.95 & $\begin{array}{l}\text { copper alloy } \\
\text { amorphous fragment }\end{array}$ & hor. 17 a5-18 & Brysbaert \& Vetters 2010, 42, tab. 3 \\
\hline TN 83 & LXIII 34/53 VI a 12.90 & copper alloy awl & hor. 17 a5-18 & Brysbaert \& Vetters 2010, 42 , tab. 3 \\
\hline TN 81 & LXIII 34/53 VI c12.96 & copper alloy wire? & hor. 17 a5-18 & Brysbaert \& Vetters 2010, 42, tab. 3 \\
\hline TN 69 & LXIII 34/43 VIA b12.91 & lead clamp & hor. 17 a5-18 & Brysbaert \& Vetters $2010,30,42$, tab. 3 \\
\hline TN 59 & LXIII 34/53 VI b12.95 & lead clamp & hor. 17 a 5-18 & Brysbaert \& Vetters 2010, 30, 42, tab. 3 \\
\hline TN 63 & LXIII 34/63 VI b12.93 & lead sheet & hor. 17 a5-18 & Brysbaert \& Vetters 2010, 30, 42 tab. 3 \\
\hline TN 90 & LXIII 34/53 VC d13.01 & $\begin{array}{l}\text { copper alloy } \\
\text { amorphous fragment }\end{array}$ & hor. $18-20$ a2 & Brysbaert \& Vetters 2010, 42, tab. 3 \\
\hline TN 91 & LXIII 34/63 VC g13.01 & $\begin{array}{l}\text { copper alloy } \\
\text { amorphous fragment }\end{array}$ & hor. $18-20 \mathrm{a} 2$ & Brysbaert \& Vetters2010, 42, tab. 3 \\
\hline TN 64 & LXIII 34/52 VC e13.01 & $\begin{array}{l}\text { lead sheet with cut- } \\
\text { marks }\end{array}$ & hor. $18-20 \mathrm{a} 2$ & Brysbaert \& Vetters 2010, 30, 42, tab. 3 \\
\hline TN 87 & LXIII 34/53 VC c13.02 & $\begin{array}{l}\text { copper alloy } \\
\text { amorphous fragment }\end{array}$ & hor. $18-20 \mathrm{a} 2$ & Brysbaert \& Vetters 2010, 43, tab. 3 \\
\hline TN 77 & LXIII 34/53 VC b13.03 & copper alloy strip? & hor. $18-20 \mathrm{a} 2$ & Brysbaert \& Vetters 2010, 43, tab. 3 \\
\hline TN 67 & LXIII 34/53 VC a13.04 & lead sheet & hor. $18-20$ a2 & Brysbaert \& Vetters $2010,30,43$, tab. 3 \\
\hline TN 68 & LXIII 34/52 VC f13.04 & lead clamp & hor. $18-20$ a2 & Brysbaert \& Vetters $2010,30,43$, tab. 3 \\
\hline TN 60 & LXIII 34/52 VC d13.04 & lead strip or clamp & hor. $18-20$ a2 & Brysbaert \& Vetters 2010, 30, 43, tab. 3 \\
\hline TN 61 & LXIII 34/52 VC c13.04 & $\begin{array}{l}\text { lead sheet with cut- } \\
\text { marks }\end{array}$ & hor. $18-20 \mathrm{a} 2$ & Brysbaert \& Vetters 2010, 30, 43, tab. 3 \\
\hline TN 92 & LXII $35 / 40$ a 12.84 & $\begin{array}{l}\text { copper alloy imple- } \\
\text { ment }\end{array}$ & hor. 17 as & \\
\hline TN 113 & LXIII 35/02 a12.84 & obsidian flake & hor. 17 a5 & \\
\hline TN 120 & LXIII 35/02 VI b12.85 & obsidian blade & hor. 17 a5 & \\
\hline TN 171 & LXIII 35/01 VI & obsidian blade & hor. 17 a5 & \\
\hline TN 183 & LXIII 35/03 VIb a12.92 & $\begin{array}{l}\text { worked fragment of } \\
\text { lapis lacedaimonius }\end{array}$ & hor. $18-20$ a2 & Brysbaert \& Vetters 2010, 31, 41, tab. 1 \\
\hline TN 218 & LXIII 34/92 VA a13.24 & $\begin{array}{l}\text { worked fragments of } \\
\text { rock crystal }\end{array}$ & hor. $20 \mathrm{a} 3-21 \mathrm{a} 0$ & Brysbaert \& Vetters $2010,31,41$, tab. 1 \\
\hline TN 863 & LXIII 35/13 IIC & $\begin{array}{l}\text { worked fragment of } \\
\text { rock crystal }\end{array}$ & unstratified & \\
\hline TN 184 & $\begin{array}{l}\text { LXIII 34/61 IVG a13.26 } \\
\text { Kilianstörung }\end{array}$ & $\begin{array}{l}\text { black serpentinite with } \\
\text { traces of saw }\end{array}$ & $\begin{array}{l}\text { unstratified } \\
\text { (above Room 1/02) }\end{array}$ & Brysbaert \& Vetters 2010, 31, 41, tab. 1 \\
\hline TN 858 & LXII 35/39 IVD a13.87 & $\begin{array}{l}\text { lapis lacedaimonius } \\
\text { chip }\end{array}$ & $\begin{array}{l}\text { hor. } 21 \mathrm{~b} 1-21 \mathrm{c} 0 \text { (abo- } \\
\text { ve Room 4/02) }\end{array}$ & \\
\hline TN 860 & LXII 35/30 IVD a13.87 & $\begin{array}{l}\text { lapis lacedaimonius } \\
\text { chip }\end{array}$ & $\begin{array}{l}\text { hor. } 21 \mathrm{~b} 1-21 \mathrm{c} 0 \text { (abo- } \\
\text { ve Room 4/02) }\end{array}$ & \\
\hline
\end{tabular}


$78 \mathrm{c}$ contained a marble weight, a clay conulus, ${ }^{124}$ a lead sheet and a piece of partly worked shell (probably abalone). A copper alloy chisel, a lead clamp and two lead spills and perhaps a hammerstone were excavated in the fill of the room. ${ }^{125}$ Room $1 / 02$ housed a small wall bracket fragment, ${ }^{126}$ a whetstone, ${ }^{127}$ two lime plaster lumps, ${ }^{128}$ an exhausted obsidian core, numerous obsidian blades and flakes, several amorphous copper alloy fragments and a copper alloy awl, lead clamps and a sheet, and a crucible fragment, ${ }^{129}$ in the fill above the floor: a clay spindle whorl, ${ }^{130}$ four amorphous copper alloy fragments, two lead sheets with cut-marks, another small lead sheet as well as two lead clamps, a lime plaster lump ${ }^{131}$ and a variety of obsidian blades and flakes. Finally, Room 4/02 contained a steatite conulus, ${ }^{132}$ a chert blade, ${ }^{133}$ two obsidian blades and a flake, a copper alloy implement and a bone pin $^{134}$ and in the fill above the floor a lapis lacedaimonius fragment with saw marks. Probably connected to this assemblage are rock crystal fragments and other partially worked stone fragments which were found in layers above the LH IIIB Final building.

The identification of Building XI as a palatial workshop has been discussed elsewhere in detail. ${ }^{135}$ The amber, glass, gold, ivory and lapis lacedaimonius have clear exotic characteristics since all are, as raw materials, foreign to the Argolid (lapis lacedaimonius) or the Aegean. In Room 78a the artisans used fine tools where they worked with gold foil on the faience vessels. It is also the intimate spatial association of again wall brackets, the ivory rod and the faience vessels in that room that points to artisans' practices which were decidedly uncommon in Mycenaean palatial contexts. The assemblages of Building XI most clearly demonstrate the difficulties to distinguish exotic materials from local objects. The artisans

comprised a circular modified sherd from a vessel base, TN 194, find spot: LXIII 35/01 VC a12.81, hor. 17 a5, and a kylix stem secondarily reworked into a clay stopper, TN 937, find spot LXII 34/79 IVb, hor. 17 a5.

${ }_{124}$ TN 147, find spot: LXII 34/95 VIC a12.68, hor. 17 a5.

125 TN 156, find spot: LXII 35/46 Säuberung Kiliangrabung 1982-83 R78c.

126 TN 229, find spot: LXIII 34/53 VI d12.98, hor. 17 a5-18.

127 TN 159, find spot: LXIII 34/53 VIA b12.87, hor. 17 a5.

128 TN 201, find spot: LXIII 34/54 VIA, hor. 17 a5; TN 202, find spot: LXIII 34/42 VIA, hor. 17 a5.

129 TN 191: LXIII 34/63 VI a12.97 + LXIII 34/63 VC, hor. 17 a5-18; Brysbaert \& Vetters 2010, 30, 41 tab. 1.

130 TN 95, find spot: LXIII 34/52 VC a13.02, hor. 18-20 a2.

131 TN 203, find spot: LXIII 34/64 VC, hor. 18-20 a2.

132 TN 166. Find spot: LXIII 35/12 VI b12.87, hor. 17 a5.

133 TN 161. Find spot: LXIII 35/12 VI a 12.88 , hor. 17 a5; perhaps an Early Helladic residual find.

134 TN 193: LXII 35/48 VI a12.88, probably hor. 17 a5, but found in the area disturbed by pit no. 123/02.

135 Kilian 1984, 56, 69 fig. 1; Maran 2004a, 13-14, 16, 17 fig. 5; Maran 2008, 50-53, 90; Rahmstorf 2008, 240-241 pl. 104; Brysbaert \& Vetters 2010, 29-31, 33-34; Kostoula \& Maran 2012, 213-217. employed various local (local functional ceramics such as the crucible, and potentially the raw materials for faience production as well), regional (obsidian, andesite, lapis lacedaimonius, lead) and materials imported from afar (gold, amber, ivory) as ingredients of their production processes. They may have worked obsidian bladelets in Room 1/02, for instance, as part of their gilding activities, while their small-scale lapidary activities may have not only provided inlays but perhaps also moulds or beads. During slack times, artisans in Building XI might have worked with lead, for instance in the mundane repairing of vessels, in soldering and repoussé activities, and in gilding. ${ }^{136}$ What the working processes in these rooms particularly highlight, is the fact that artisans' practices connected to these materials cross purely local or completely exotic activities and cannot be characterized as either one or the other. Finally, the familiarity or unfamiliarity of materials or objects would probably have been conceived quite differently by the artisans in Building XI, and the final consumers of the goods produced.

\section{Discussion}

For each of the case studies, those items that are rare in comparable contexts, as outlined above (Exotica in archaeology), were discussed to highlight how such items are still frequently considered as being foreign objects and that exotica are conceived of as being rare, valuable and imported from distant lands. The term exotica is thus still easily taken for granted. Many archaeologists have used it in such a way, as clearly illustrated in several recent papers, ${ }^{137}$ whereas both Maran and Panagiotopoulos have recently commented on the fallacy of adopting this static approach to exotica. ${ }^{138}$

We believe, however, that a much more nuanced and contextualized approach is presented here. After the above review, therefore, we would like to move beyond the initial definition based on distance and non-local origin linked to the concept of exotica and evaluate the Tirynthian examples according to the additional definition referred to above which emphasizes the contextualization and dynamic nature of the concept. The conducted interviews (Tables 1-2) indicated that even contemporary viewpoints on what constitutes exotica do not necessarily provide the same answers. What do seem generally accepted are their characteristics. So if exotica can be considered differently depending on one's viewpoint it seems that the background of the viewer (professional and social perspectives and their overall context in which they move), has an in-

\footnotetext{
136 Mossman 2000, 91; see also Brysbaert \& Vetters 2010, 34.

137 Vianello 2011b; van Wijngaarden 2012; Foster 2008, 327-330.

138 Maran 2012; Panagiotopoulos 2012.
} 
fluence on the value(s) imbued on materials and objects. Can we then still differentiate between what exotica are and what they are not, which criteria can we use for this differentiation and is there a point in doing so?

In investigating our case study materials via a chaine opératoire approach, some very useful results came to the forefront as the discussions per case study may have already indicated. First, the activities that artisans conducted in both phases of the LH IIIB Middle Building (case studies 1A and 1B) suggest that several artisans collaborated closely together while they were processing materials towards finished produce. As part of their day-to-day practices, they shared materials and possibly knowledge about these materials and about how to process them best. That the artisans in these workshops, furthermore, combined day-to-day practices with clearly non-Mycenaean ways of conducting business became evident by the presence of several items that were called exotica in the past and more recent literature. ${ }^{139}$ The chaine opératoire approach, combined with contextual analyses of the finds from this workshop, illuminates the complexities of some of the characteristics that determine an item or a practice to be exotic. So far, this combined approach has provided evidence for the continuous import of exotic raw materials, half-finished/manufactured as well as finished products. However, these were either actively modified in craft activities, as in the case of the ostrich egg shell (case study $3 \mathrm{~A}$ ) or the metal finds (case study 1A, e.g. the javelin mould). They also became hybridized in local practices, as was the case for the gilded faience vessels (case study 3B). In choosing this vessel shape, the artisans consciously emulated in part Near Eastern prototypes, but equally consciously modified the vessel shape into a typical Mycenaean ritual vessel for libations, i.e. a rhyton. Artisans/builders may have also reused certain materials for mundane local needs at the end of their life span, as in the case of the fragmentary stone vase employed as building material (case study $3 \mathrm{~A}$ ).

These examples indicate that an interpretative approach to exotica, purely based on notions of the material's distant geographic origin, does not do justice to people's apparently changing appreciation and value assignments to such materials. ${ }^{140}$ Also, the interpretation of non-local materials or objects as being exotic or being thoroughly assimilated into the local material culture can only be credible through contextual analysis. Artisans' different value assignments possibly combined with practical needs are evident, for instance, in the different amounts of Melian obsidian and the scarce lapis lacedaimonius (case study 3B), indicating different valuations connected

139 For instance: Vianello 2011b; van Wijngaarden 2012; Foster 2008, 327-330.

140 See also Brysbaert 2008, 175-178. to such materials despite their relatively similar provenience distance.

The interview results (Tables 1-2) made it obvious that what is deemed exotic depends, seemingly, on a combination of both the geographical and the cultural viewpoint of the observer or of those that interact with the items themselves. Moreover, the perceived cultural distance is indicative, in that additional value is given to items that are not part of that society's familiar surroundings, even if these items are in fact present within that familiar context at that specific point in time. A clear example is the repeated presence of African musical instruments or Indonesian furniture that interview participants have in their own homes. As such, people seem to value the distance over which these items may have travelled, as well as their own unfamiliarity with the items, several aesthetic and technical qualities which the items contain, and the fact that the owner distinguishes him/herself from people around him/her by owning such items. This indicates values incorporated into the make-up of the items (materials from afar, made by people who are from afar), possibly accumulated values obtained in their circulation patterns (travelled from afar), and being consumed in a context where they seemingly are distinct from everything else and, as such, receive frequent attention and desire. The viewpoint from which one starts is also crucial in the study of archaeological remains and the social practices that they may represent. This may be exemplified by, for instance, certain motivations behind Hatshepsut's expeditions to Punt and by the controlling elites of the Aegean, over the circulation of and access to specific hard-to-get materials such as gold, amber, carnelian, lapis lazuli, copper and tin, and possibly also bronze. Our western viewpoint is likely to differ from those of the past about specific objects or features, as Burns pointed out over a decade ago $;{ }^{141}$ all too often we still project our viewpoints onto others, present or past. ${ }^{142}$ Most people, though, would agree that exotica exude high value assignments as the result of a combination of highly skilled production, (possibly even by artisans from elsewhere), with exclusive and rare raw materials, circulation patterns that incorporate accumulative life histories of such items, and consumption practices in specific closed circles of people that have very targeted socio-politically imbued agendas. These circles of people may, furthermore, be in control over the access to these exclusive and rare raw materials and

\footnotetext{
141 Burns 1999.

142 Heymans \& van Wijngaarden $(2011,124)$ mention, for instance, that "low value manufactured exotics" are "... often not made of valuable raw materials". However, they do mention ivory and semi-precious stones as a raw material for some of these. Moreover, the workmanship associated with these items, is according to the authors (same page), not highly specialized. These are clearly etic standards which determine, though, what materials are valuable and which skills highly specialized.
} 
the artisans with the knowledge to transform them. ${ }^{143}$ The elephant is a classic example. Elephant tusks appear to have been considered exotic in the past, since ivory possession and working have often been associated with elite consumption patterns and palatial power symbols in the Aegean Bronze Age and beyond. ${ }^{144}$ Tusks, moreover, were often depicted on Egyptian murals as gifts, stocks being stored by the ruler or being brought in by people from afar. Tusks as raw material were found in Aegean palatial contexts and workshops where these were processed may have been identified. ${ }^{145}$ Having thus been hunted for millennia for its tusks, the animal itself is now protected but the action of the hunt is still considered exotic, rare and valuable due to exclusive access. ${ }^{146}$ As such, hunting elephants in specific restricted social circles and the continuous quest for ivory tusks confirm the high value of ivory, or least the physical effort and cost to obtain it.

As mentioned earlier, the $O E D$ definitions mention one specific aspect associated with exotic: something specially produced, and to this we will now turn in more detail. In Table 8 , the five-tier classification as presented and critiqued above (Approaching the production of exotica) is tested against the various finds from our case studies mentioned and discussed in detail (Workshops and activity areas in Late Bronze Age Tiryns). This grouping, although initially helpful, raises several issues concerning distance, whether geographic or cultural and whether we need to consider specific geographical distances (measured in $\mathrm{km}$ ) before something becomes an import. ${ }^{147}$ It became evident that geographical distances may only be one factor of the perceived distance of an item or material, especially in relation to materials such as obsidian, lapis lacedaimonius and lead as in case study $3 \mathrm{~B}$, or the African musical instruments and Indonesian furniture, as in the interview series. Different stones were worked in palatial contexts such as Tiryns (case study 3B), but what it took for these materials

143 See Brysbaert 2008, 174 for such interpretation relating to painted plaster manufacture and use.

${ }^{144}$ Krzyszkowska \& Morkot 2000, with references; Lapatin 2001 with references.

${ }^{145}$ For Zakros palace, for example: Platon, E.M. 1988, 69, 126 pl. 19; Platon, N. 1974, 100. See Tournavitou 1995 for workshops.

146 http://www.guardian.co.uk/world/2012/apr/15/spain-king-juancarlos-hunting, accessed 06/05/2012. For historical periods, see e.g. Shalem 2004 with references.

147 See recently Cline 2005, 45-47, but not without problems since he, for instance, uses the boundaries and borders between countries as the limit from when onwards something becomes import or export, such borders are a modern, thus etic, invention. Some items also do not have a straight production line and may make several detours, as part of transport or the production chain, before they arrive at their final destination, also not taken into account by Cline 2005, 47 . The ostrich egg example from Tiryns is illustrating this very aptly. to get there is not clear. ${ }^{148}$ Carter called obsidian in the Bronze Age Minoan context exotic because of the distance that the material had to bridge in order to form a supply of semi-raw obsidian material to Crete, implying that distant, possibly dangerous journeys may have brought along added value to such materials. ${ }^{149}$ Also Tykot's recent article about obsidian on the fringe of the central Mediterranean sphere mentions the material's exotic nature. ${ }^{150}$ However, due to the ubiquity of obsidian tools in Late Bronze Age Mycenaean contexts the validity of characterizing them as exotic and as functioning as tools of distinction is somehow questionable. Inquiring whether materials from locations such as Melos (about $100 \mathrm{~km}$ away from Tiryns), Aigina, Poros and Methana (between 50 and 80 $\mathrm{km}$ from Tiryns) should be considered local or imported, is, therefore, less crucial, especially since Helms also pointed out that geographical distance is not always considered neutral by each cultural group. ${ }^{151}$

Yet more complex are the ostrich egg fragment (case study $3 \mathrm{~A}$ ), the glass beads (case study $1 \mathrm{~A}$ and $1 \mathrm{~B}$ ), and the copper alloy items (several case studies, especially $1 \mathrm{~A}$ ). The raw materials for each of these went through at least one production stage possibly at or near the source of the raw material, before they were brought to the Aegean. Employing the chaine opératoire approach forces one to consider these important technical and social details. For example: the ostrich eggs from Egypt, Libya or the Near East were first drained of their content and possibly polished before being shipped to the Aegean. They were subsequently shaped and embellished locally into rhyta with metal, glass, and semi-precious stones. ${ }^{152}$ Such an ostrich egg can certainly be considered an exotic item even though by re-modifying it, it becomes locally appropriated. Despite its modification into a rhyton, the object has high value due to its technical and material make-up, where it was made (and possibly by whom), and its restricted use context. This ostrich egg could, thus, fit several of the five production mode types (see Table 8), both technically and socially, but these production modes illustrate that they are, by far, not flexible enough when employed in a contextualised study. What we would need is the possibility to interconnect and combine the production

\footnotetext{
148 See Bevan 2007, 163-165 on Mycenaean-style stone vessel types versus Knossian production; Tournavitou 1995, 213-236 on stone working in the Mycenaean House of the Shields and adjacent areas; Maran 2008 and Brysbaert \& Vetters 2010 with references on small lapidary workshop at Tiryns; Varti-Matarangas et al. 2002; and Brysbaert 2014b, in press, for architectural uses of stones at Tiryns.

149 Carter 2004, 99, 101 on the possible indirect obtaining of exotic materials such as obsidian at Mochlos.

150 Tykot 2011.

151 Helms 1993, 3

152 Brysbaert 2013, 250-252.
} 
mode types according to contextual needs and reformulate new ones when and if the context dictates this.

By considering the copper alloy objects, other complex patterns of material processing by skilled artisans, sometimes through sharing, emerge. Published evidence points to copper ore extraction, smelting and probably casting of ingots on $\mathrm{Cy}$ prus. ${ }^{153}$ However, so far, only one oxhide ingot stone mould has been found, in the palace of Ras ibn Hani, close to Ugarit, in Syria, even though ingot production must have taken place on Cyprus as well, possibly using sand moulds. ${ }^{154}$ The ingots were then transported all over the East Mediterranean, for which we have the telling evidence from, for instance, the Ulu Burun and the Cape Gelidonya shipwrecks, both carrying ingots of almost pure copper and tin. ${ }^{155}$ As previously discussed, even a pure copper oxhide ingot is not a raw material but is the result of several previous steps in a complex process of converting metallic ores into finished objects, ${ }^{156}$ and as such, different activities in this complex set of processes may divide the chaine opératoire of each activity into different locations. ${ }^{157}$ To compound this further, scrap bronze was also found on the Gelidonya shipwreck next to a number of pure copper ingots and a few bronze ingots, cast in oval shapes. ${ }^{158}$ These bronze ingots and bronze scraps were ready to be reused. ${ }^{159}$ In Tiryns, a bronze ingot the details of which have been published by Kilian ${ }^{160}$ was found in the south wall of Room 215 in the LH IIIB Middle complex (case study 3A). While the notion of bronze oxhide ingots has been disputed rather convincingly by Muhly and others, ${ }^{161}$ the rectangular Tiryns ingot definitely constitutes a bronze ingot. As such, tracing the chaine opératoire of it is much more complex than that for a pure copper ingot since artisans present in different locations may have produced several items contributing to the bronze ingot's make-up. Artisans may have recycled and thus mixed several

153 See most recently Muhly 2009; several papers in Betancourt \& Ferrence 2011.

154 Van Lokeren 2000, 275 implies as much with his experiment.

155 Hauptmann et al. 2002; most recently Pulak 2010 with references; Kassianidou 2012, personal communication.

156 Hauptmann et al. 2002, 5; Tylekote 1982; Zwicker 1985; Kassianidou 2009; Gale 2011, 214.

157 For metal production: Pigott 2011, 276; for ostrich egg rhyton production: Brysbaert 2013.

158 The bronze ingots are, as such, not mentioned by Bass 2010, 800802, but they are in Bass 1975, 8, 50, 52.

159 See also Brysbaert 2011b; on the topic of bronze ingots, see Kassianidou 2012, personal communication; Bass 1975; 2010 on the full assemblage of Cape Gelidonya.

160 Kilian 1988, 130 n. 53, 140 fig. 37,4; some percentages of the elements, detected partly by atomic absorption spectroscopy and partly neutron activation analysis, however, are erroneously cited: copper constituted 82\%, tin 13.2\% (communication E. Pernicka 2012 on sample/ lab. no. FG-880115).

161 Muhly 2009, 18-20. discarded items and the entire process of interacting with these materials may have preceded the production of such an ingot, which then arrived in Tiryns, as a finished product, yet to be reused as a raw material. ${ }^{162}$

By re-melting copper or bronze scrap, it also seems that people at Tiryns conducted similar practices as artisans did elsewhere, as found, for instance, in our first case study, where such scrap may have been remoulded into a weapon's part or where it could have been used to colour Egyptian blue (case study 1A). ${ }^{163}$ Bronze as the metal phase of the Egyptian blue pigment composition had been attested at Knossos, Akrotiri and Mycenae. ${ }^{164}$ Traces of bronze have also been detected in Egyptian blue on the wall paintings from Phylakopi, Orchomenos, and at Tell el-Dab'a. ${ }^{165}$ While some of the original raw materials may have had a decidedly exotic origin, the artisans who locally used, reused and adapted these materials, embedded these in their local practices, as recognized from finds at several Mycenaean palatially controlled workshops. As such, the processes involved in reusing bronze scrap in pigment production fit, not just one, but a number of the five production modes. The copper providing the blue hue for the Egyptian blue pigment may be recycled ${ }^{166}$ and the tin (when present too), indicates the employment of recycled copper alloy or bronze scrap to colour the pigment. Tin may have been sourced from Afghanistan, West Iran, or the Taurus in Turkey. ${ }^{167}$ The exotic components fused into a hybrid composition forming the Egyptian blue pigment may not betray, at least visibly, its original constituents (unlike the example of the ostrich egg rhyta). However, the end-product seemed to have had a specific value to the palace since the Egyptian blue was likely produced in its (confined) workshops. Blue coloured glass was mentioned in the Linear B tablets ${ }^{168}$ which may be a reference to this blue glass-based pigment too.

Finally, raw glass production is still not accounted for in the Aegean during the Bronze Age but made it into the Aegean as ingots coming possibly from Egypt or from the Syro-Levantine coast. Several coloured glass ingots are known from the Ulu Burun wreck, some coloured with cobalt which is, most often, native to Egypt. ${ }^{169}$ Faience was made locally in the Aegean, maybe also on the Greek Mainland as hinted at

\footnotetext{
162 Even if the copper derives from ores in Laurion and thus was not a long-distance import, the alloyed tin was in all probability not native to the Eastern Mediterranean region.

163 E.g. Shortland 2000 for the same phenomenon at Amarna, see also Brysbaert 2007.

164 Philippakis et al. 1976.

165 Brysbaert 2007b; 2008.

166 Philippakis et al. 1976; Brysbaert 2008, 135-136.

167 Muhly 1993; Yener et al. 1993; most recently on the multiple sources of tin: Pigott 2011, esp. 275, 277, 281.

168 See e.g. Bennet 2008, 159-160; Nightingale 2008, 79-80.

169 But see now Panagiotaki 2008, 50-51.
} 
by Panagiotaki but the colouring materials, if copper-based, came again from elsewhere. ${ }^{170}$ As such we recognize in the faience vessels from Building XI (case study 3B), yet again, a hybridized mixture of materials and skills, resulting in locally appropriated items.

What emerged from the contextual analysis of the case studies is the fact that objects and raw materials often change their status as exotic during their life history as a result of recycling or reuse, thus secondary uses that obliterate characteristics that once set them apart from the local material culture. In that sense, one could argue that materials which were often recycled, such as metals, may drop in value due to the fact that they can be reused so often. On the other hand, the fact that these recyclable metals were so often reused and so strongly sought after, even after the palatial collapse, ${ }^{171}$ may also indicate the opposite. Their value may have become higher and higher, not only because they were so often recycled, but because their supply line was less fluid, thus more wanted. Their limited circulation, thus, raised the value, at that point in time.

\section{Conclusion}

The work conducted in the Tiryns workshops and the concentrations of foreign items present in these contexts suggests people who possibly came from elsewhere, who were familiar with foreign practices or may have learnt them elsewhere. Therefore, arguments for resident Cypriots solely on the basis that Cypro-Minoan signs are attested at Tiryns, ${ }^{172}$ or that
Ugaritians were present because Ugaritic cuneiform signs were carved in the ivory rod, ${ }^{173}$ have already been shunned. ${ }^{174}$ In order to better understand the social context of these objects, they need to be correlated with other material remains. So far we focused mainly on production and materials, but also consumption patterns need scrutiny and these may not fit in any specific classification system as outlined in Table 8. The material evidence from Tiryns suggests several non-local or hybrid practices, illustrated through so-called exotica, practices which may have overlapped with local ones in many configurations. These may reveal a complex series of technological and social networks, both local and beyond, where objects and practices became indistinguishable. ${ }^{175}$

Wall brackets, for instance, predominantly from the East and Cyprus, and also found on the Ulu Burun shipwreck, ${ }^{176}$ were, at Tiryns and Cyprus, often found in places where metallurgical production was conducted. ${ }^{177}$ The LH IIIB Middle building at Tiryns (case study 3B) contained a wall bracket potentially imported from Cyprus along with locally made ones, all associated with a metallurgical workshop area. All were probably used in a similar way, thus indicating shared practices by the users of both, the Cypriot wall bracket and the local ones, and probably reflecting a practice better known from Cyprus and the Near East, as argued convincingly by Rahmstorf. ${ }^{178}$ We cannot be sure of the ethnicity of the wall bracket users in Tiryns but socially, these people may have been linked through similar craft activities, as artisans colleagues so to speak, thus forming a specific Tirynthian network, based on shared technologies, possessions, knowledge,

Table 8. Production mode categories against objects from Tiryns' palatial case study contexts, the place names in bold: to be considered local, or not?

\begin{tabular}{|c|c|c|}
\hline Mode of production & Item & Case study \\
\hline Elsewhere, imported & $\begin{array}{l}\text { Likely Cypriot wall bracket } \\
\text { Bronze violin bow fibula }\end{array}$ & $\begin{array}{l}1 \mathrm{~B} \\
2,1 \mathrm{~B}\end{array}$ \\
\hline Locally, with imported materials, foreign or local style & $\begin{array}{l}\text { Ivory inlay } \\
\text { Gold foil overlay on faience }\end{array}$ & $\begin{array}{l}1 \mathrm{~B} \\
3 \mathrm{~B}\end{array}$ \\
\hline Locally, with local materials, imitating foreign objects & $\begin{array}{l}\text { Tiryns-made wall bracket } \\
\text { Faience rhyton heads }\end{array}$ & $\begin{array}{l}1 \mathrm{~B}, 3 \mathrm{~B} \\
3 \mathrm{~B}\end{array}$ \\
\hline Locally, with imported/local materials, by local/foreign artisans, knowing foreign skills & Ivory rod with cuneiform signs ${ }^{1}$ & 3B \\
\hline Locally, with local materials, by local artisans, with skills possibly learned elsewhere & $\begin{array}{l}\text { Obsidian tools (Melos) } \\
\text { lapis lacedaimonius stone } \\
\text { Andesite grinding stones } \\
\text { (Aigina, Poros, Methana) }\end{array}$ & $\begin{array}{l}\text { All } \\
3 \mathrm{~B} \\
3 \mathrm{~B}\end{array}$ \\
\hline
\end{tabular}

${ }^{1}$ This object could also just have been locally used but produced elsewhere altogether.

170 See Foster 1979; Evely 2000, 445-469: already introduced since the Early Bronze Age after which polychromatic objects were produced as well. See also Panagiotaki 2008, 50-51.

171 E.g. Knapp 2000 and see scrap metal on the Cape Gelidonya shipwreck mentioned above.

172 Vetters 2011b.
173 Cohen et al. 2010.

174 See e.g. Brysbaert \& Vetters 2010; Vetters 2011b; more decisive are Cohen et al. 2010, 16-17.

175 Cohen et al. 2010; Kostoula \& Maran 2012; Vetters 2011b.

176 For an overview of sites with wall brackets see Rahmstorf 2008, 95107.

177 Rahmstorf 2008, 110.

178 Rahmstorf 2008, 110. 
belief systems and practices which may link into similar technological and socio-economic networks beyond Tiryns into the East Mediterranean sphere.

That Tiryns was seemingly part of a socio-economic East Mediterranean network is further reinforced by the presence, of several other items there, namely an ivory rod from the workshop in Building XI where specialized crafts were possibly carried out by foreign workers ${ }^{179}$ (case study $3 \mathrm{~B}$ ), the presence of Mycenaean sphendonoid weights conforming to an Egyptian-Levantine standard, ${ }^{180}$ plenty of incised CyproMinoan signs on imported and local vessels, ${ }^{181}$ a clay ball with a Cypro-Minoan inscription in a post-palatial layer above Building XI, ${ }^{182}$ and a fragmentary Cypro-Levantine lamp in the Lower Town Northeast. ${ }^{183}$

As previously discussed, ${ }^{184}$ such objects cannot be seen as mere exotica but should be understood within their specific context, taking into account both their material makeup (technical production processes and materials), and their materiality (who made them, where, how they socially functioned and in which context, used by whom and for what purpose).

Bringing all the material evidence of the palatial period together and based on spatial and contextual associations of several foreign artefacts that do not appear to be deposited intentionally, it seems that Tirynthian contacts with Cyprus and the Levant went beyond mere trade connections. Various scholars working in Tiryns have now convincingly suggested the presence of either a small group of Cypriot or Levantine people in Tiryns, possibly artisans, or local people who had been exposed long enough to Cypriot and Levantine lifestyles to have taken over several of their practices, some of which may even have ritual or magical connotations, ${ }^{185}$ especially when considering the link between metallurgical activities and the presence of the ivory rod as a potential ritual paraphernalia. These people, local or foreign, ${ }^{186}$ would not have considered any of their possessions exotic but may have employed them as diacritical devices, in order to include and exclude others who were not part of their craft, or employed them on a ritual- and knowledge-based level, to either create asymmetries in exist-

179 Maran 2008, 90; Cohen et al. 2010; Kostoula \& Maran 2012.

180 Rahmstorf 2008, 159-163.

181 Hirschfeld 1996.

182 Vetters $2011 \mathrm{~b}$

183 Maran 2004a, 25 fig. 15; Maran \& Papadimitriou 2006, 120 fig. 30.

184 Cohen et al. 2010; Maran 2012.

185 On ritualized skilled practice, see Voutsaki 1995, 9; on the magical connotation of the act of crafting, see Brysbaert 2008, 167-168, 183184.

${ }^{186}$ In allegiance with Bhabha's interest in the ambivalence of identity in contact zones, Bhabha 1994, 37. ing hierarchies, or just as the material expression of shared understandings and practices, known and learnt elsewhere.

We, as authors, agree that exotica consist of rare and exclusive raw materials which may have magical properties in themselves, often manufactured by highly skilled artisans (possibly even foreigners), through hybrid usage of materials, styles and technologies into goods, features and items. We also agree that these items were meant to be pleasing and aesthetically attractive since they needed to fulfil specific socio-economic roles in circles of elites but possibly too in artisans' contexts, the former which may have controlled the access to and circulation of any part of the totality of such items. It thus seems that most of these characteristics are similar for people in the past and present alike. ${ }^{187}$

This should indicate that our point in the present paper is not to discourage the employment of the term exotica-it actually suits us in many different contexts-as long as we consider the implications and the complexity it entails. As such, we should be aware of the dangers involved in calling something exotic uncritically and de-contextualized. Moreover, it should also be divested of its link to a western attitude of attributing the distance value it may imply to a superior context, thus robbing the appropriators off their own viewpoint and understanding. If misunderstood or taken in its traditional western meaning, calling something exotic is seriously misleading, because it is a very static term for changing stages in material production, circulation and consumption and it does not take into account the socio-political, economic and religious contexts and contact zones of all the people involved, objects and practices in which these items were employed and with which they interacted. A telling example can be understood in Sacconi's work interpreting, to our feeling correctly, certain quantities of bronze present in palaces, like Knossos, purely as the payment for linen garments (tablet KN L 693). Even the ideogram $\left({ }^{*} 167\right)$ on tablets KN Oa 730, Oa 733 and Oa 734 refers to the weight of the bronze as its value, not its potential far-away origin or its shape. ${ }^{188}$

In order then to avoid this static connotation often linked to exotica, we attempted to illustrate that their production, circulation and consumption are ultimately parts of a series of social and professional processes, not static stages (inasmuch as Leroi-Gourhan also saw the chaine opératoire as processes ${ }^{189}$ ). During these processes people shared materials, equipment, skills, knowledge, belief systems and practices that overlap and indicate people's active presence in several local, regional, and interregional dynamic networks, moving in several directions and axes. Those processes then emphasize contact zones where

\footnotetext{
187 Foster's 2008 examples are indicative.

188 Sacconi 2005, 73-74.

189 Brysbaert 2011a.
} 
hybrid materials, objects and identities can be acquired, transformed and translated into something/someone new, rather than places of origin and ethnic identities. ${ }^{190}$

Exotica, therefore, can probably best be understood, on the one hand, as those materials, objects, phenomena and places that include and exclude as part of processes, especially when seen from a western perspective, ${ }^{191}$ whilst, on the other, not all parties surrounding such items may perceive these as exotic. One could, therefore, still maintain that when one possesses, has access to, or understands such items or practices, one becomes part of the social group that has similar possessions, understanding or access to them, but this could be disconnected from power hierarchies. One may also be excluded if one has no such access or understanding of the item or phenomena, but this should only be understood and interpreted as such when the specific material context study warrants it.

The value of exotica may thus not sit with only foreign materials and objects, but be best considered in relation to hybrid practices, which consist of both people's interactions and the various materials, intertwined and entangled with one anoth$\mathrm{er}^{192}$ as our case studies and their analyses have illustrated. It is the practices of a society or an individual, and the associations with such and other more mundane objects that form their multiple and dynamic identities, both of objects and people. As in the past when these practices changed, people's identities changed as well and, as such, not all sharing of such practices needs to be defined in the context of dominators and dependents. It is thus the in-depth examination of material finds and their technologies on the ground (i.e. in their specific contexts) that allows us, as archaeologists, to focus on all, indigenous and other, groups that make up the entire context we study. Therefore, the wall-brackets may have meant nothing special to the foreign artisans at work in Building XI while local apprentices, if present in the same workshop, may have seen advantages in appropriating its use in order to facilitate a mutually agreeable working environment.

\section{ANN BRYSBAERT \\ Faculteit Archeologie \\ Universiteit Leiden \\ Reuvensplaats 3-4 \\ NL-23I I BE Leiden, Netherlands \\ a.n.brysbaert@arch.leidenuniv.nl \\ anbII@le.ac.uk (until Jan 30, 20I4)}

\section{MELISSA VETTERS}

School of Archaeology and Ancient History

University of Leicester

University Road

Leicester LEI 7RH, UK

mv95@le.ac.uk

\footnotetext{
190 After Counts 2008, 112.

191 van Dommelen \& Rowlands 2012, 27.

192 van Dommelen 2006, 119, referring to N. Thomas's crucial work on this theme.
}

\section{Bibliography}

Bass, G.F. 1975. Archaeology beneath the sea, New York.

Bass, G.F. 2010. 'Cape Gelidonya shipwreck', in The Oxford handbook of the Bronze Age Aegean, ed. E.H. Cline, Oxford, 797-803.

Bennet, J. 2008. 'Palace ${ }^{\mathrm{TM}}$ : Speculations on palatial production in Mycenaean Greece with (some) reference to glass', in Vitreous materials in the Late Bronze Age Aegean (Sheffield Studies in Archaeology, 9), eds. C.M. Jackson \& E.C. Wager, Oxford, 151-172.

Betancourt, P.P. \& S.C. Ferrence, eds. 2011. Metallurgy: Understanding how, learning why. Studies in honor of J.D. Mubly (Prehistory Monograph, 29), Philadelphia.

Bevan, A. 2007. Stone vessels and values in the Bronze Age Eastern Mediterranean, Cambridge.

Bhabha, H. 1994. The location of culture, London.

Brysbaert, A. 2004. Technology and social agency in Bronze Age Aegean and Eastern Mediterranean painted plaster, $\mathrm{PhD}$ thesis, University of Glasgow.

Brysbaert, A. 2007a. 'Cross-craft and cross-cultural interactions during the Aegean and Eastern Mediterranean Late Bronze Age', in Mediterranean crossroads, eds. S. Antoniadou \& A. Pace, Athens, 325-359.

Brysbaert, A. 2007b. 'A technological approach to the painted plaster of Tell el-Dab'a, Egypt: Microscopy and scientific analysis', in Taureador scenes in Tell el-Dab'a (Avaris) and Knossos, eds. M. Bietak, N. Marinatos \& C. Palivou, Wien, 151-162.

Brysbaert, A. 2008. The power of technology in the Bronze Age Eastern Mediterranean. The case of painted plaster (Monographs in Mediterranean Archaeology, 12), London.

Brysbaert, A. 2011a. 'Introduction. Tracing social networks through studying technologies', in Tracing prehistoric social networks through technology: A diachronic perspective on the Aegean, ed. A. Brysbaert, London, $1-11$.

Brysbaert, A. 2011b. 'Technologies of re-using and recycling in the Aegean and beyond', in Tracing prehistoric social networks through technology: A diachronic perspective on the Aegean, ed. A. Brysbaert, London, 183-203.

Brysbaert, A. 2013. “'The chicken or the egg?” Interregional contacts viewed through a technological lens at Late Bronze Age Tiryns, Greece', OJA 32:3, 233-256. 
Brysbaert, A. 2014a, in press. 'Talking shop: multicraft workshop materials and architecture in prehistoric Tiryns, Greece', in Material crossovers: Knowledge networks and the movement of technological knowledge between craft traditions, eds. K. Rebay-Salisbury, L. Foxhall \& A. Brysbaert, London.

Brysbaert, A. 2014b, in press. 'Set in stone? Structure's symbolism at Bronze Age Tiryns, Greece', in R. Frederiksen, S. Müth, P. Schneider \& M. Schnelle (eds.), Fokus Fortifikation. Papers of the Conference on the research of ancient fortifications at the Acropolis Museum in Athens, 6-9 December 2012, Athens.

Brysbaert, A. \& M. Vetters 2010. 'Practicing identity: a crafty ideal?', Mediterranean Archaeology and Archaeometry $10: 2,25-43$.

Burns, B.E. 1999. Import consumption in the Bronze Age Argolid (Greece): Effects of Mediterranean trade on Mycenaean society, $\mathrm{PhD}$ thesis, University of Michigan.

Carter, T. 2004. 'The stone implements', in Mochlos IC. Period III. Neopalatial settlement on the coast: The Artisans' 2uarter and the Farmhouse at Chalinomouri (Prehistory Monograph, 9), eds. J.S. Soles \& C. Davaras, Philadelphia, 61-107.

Cline, E.H. 2005. 'The multivalent nature of imported objects in the ancient Mediterranean world', in EMPORIA. Aegeans in the Central and Eastern Mediterranean. Proceedings of the 10th International Aegean Conference, Athens, Italian School of Archaeology, 14-18 April 2004 (Aegaeum, 25), eds. R. Laffineur \& E. Greco, Liège \& Austin, 45-51.

Cohen, C., J. Maran \& M. Vetters 2010. 'An ivory rod with a cuneiform inscription, most probably Ugaritic, from a final palatial workshop in the Lower Citadel of Tiryns', AA 2010:2, 1-22.

Counts, D.B. 2008. 'The master of the lion: representation and hybridity in Cypriot sanctuaries', AJA 112:1, 3-27.

Damm, U. 1997. Die spätbronzezeitlichen Miniaturgefäße und Hoblgeformten Stiere von Tiryns. Eine Analyse der Form und Funktion, $\mathrm{PhD}$ thesis, Universität Bonn.

Dietrich, M. \& O. Loretz 2011. 'Rhabdomantie im mykenischen Palast von Tiryns. Das Fragment eines kurz-keilalphabetisch beschrifteten Elfenbeinstabs', UgaritF 42, 141-159.
Dobres, M.-A. 2000. Technology and social agency. Outlining a practice framework for archaeology, Oxford.

Dobres, M.-A. 2010. 'Archaeologies of technology', Cambridge Journal of Economics 34, 103-114.

Evely, R.D.G. 2001. Minoan crafts: Tools and techniques. An introduction (SIMA 92:2), Jonsered.

French, E. \& P. Stockhammer, 2009. 'Mycenae and Tiryns: the pottery of the second half of the thirteenth century BC - contexts and definitions', BSA 104, $175-232$.

Foster, K.P. 1979. Aegean faience of the Bronze Age, New Haven \& London.

Foster, K.P. 1989. 'Translations into clay: inspiration and imitation in Minoan pottery', in Cross-craft and cross-cultural interactions in ceramics (Ceramics and Civilization, IV), eds. P.E. McGovern, M.D. Notis \& W.D. Kingery, Westerville, OH, 31-44.

Foster, K.P. 2008. 'A taste for the exotic', in DAIS. The Aegean feast. Proceedings of the 12th International Aegean Conference. University of Melbourne, Centre for Classics and Archaeology, 25-29 March 2008 (Aegaeum, 29), eds. L.A. Hitchcock, R. Laffineur \& J. Crowley, Liège \& Austin, 327-338.

Gibson, J.J. 1979. The ecological approach to visual perception, Boston, MA.

Hasaki, E. 2011. 'Crafting spaces: archaeological, ethnographic, and ethnoarchaeological studies of spatial organization in pottery workshops in Greece and Tunisia, in Pottery in the archaeological record: Greece and beyond (Gösta Enbom Monographs, 1), eds. M.L. Lawall \& J. Lund, Aarhus, 11-28.

Hauptmann, A., R. Maddin \& M. Prange 2002. 'On the structure and composition of copper and tin ingots excavated from the shipwreck of Uluburun', BASOR $328,1-30$.

Helms, M.W. 1988. Ulysses' sail. An ethnographic odyssey of power, knowledge, and geographical distance, Princeton.

Helms, M.W. 1993. Craft and the kingly ideal. Art, trade and power, Austin.

Heymans, E. \& G.J. van Wijngaarden 2011. 'Low-value manufactured exotics in the Eastern Mediterranean in the Late Bronze and Early Iron Ages', in Exotica in the prehistoric Mediterranean, ed. A. Vianello, Oxford, 124-136. 
Hirschfeld, N. 1996. 'Cypriots in the Mycenaean Aegean', in Atti e Memorie del Secondo Congresso Internazionale di Micenologia, Roma-Napoli, 14-20 Ottobre 1991 (Incunabula Graeca, 98:1), eds. E. de Miro, L. Godart \& A. Sacconi, Roma, 289-297.

Hughes-Brock, H. 1999. 'Mycenaean beads - gender and social contexts', OJA 18:3, 277-296.

Ingold, T. 1999. 'Foreword', in The social dynamics of technology. Practice, politics, and world views, eds. M.-A. Dobres \& C.R. Hoffman, Washington \& London, vii-xi.

Ingold, T. 2011. Being alive. Essays on movement, knowledge and description, London \& New York.

Kakoulli, I. 2009. 'Egyptian blue in Greek painting between 2500 and 50 BC', in From mine to microscope: Advances in the study of ancient technology, eds. A. Shortland, I. Freestone \& Th. Rehren, Oxford, 101-112.

Kassianidou, V. 2009. 'Oxhide ingots in Cyprus', in $O x$ hide ingots in the Central Mediterranean, eds. F. Lo Schiavo, J.D. Muhly, R. Maddin \& A. Guimlia-Mair, Roma, 41-82.

Kenoyer, J.M. 2000. 'Wealth and socioeconomic hierarchies of the Indus Valley civilisation', in Order, legitimacy and wealth in ancient states (New Directions in Archaeology), eds. J. Richards \& M. Van Buren, Cambridge, 88-110.

Kilian, K. 1981. 'Ausgrabungen in Tiryns 1978, 1979. Bericht zu den Grabungen', AA 1981, 149-194.

Kilian, K. 1983. 'Ausgrabungen in Tiryns 1981. Bericht zu den Grabungen', $A A$ 1983, 277-328.

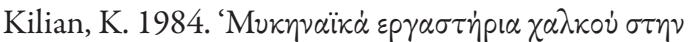

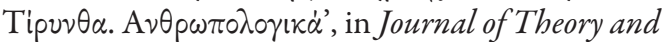
Practice 6, 55-57, 69-72.

Kilian, K. 1985. 'Violinbogenfibeln des griechischen Festlandes', PZ 60, 145-203.

Kilian, K. 1986. 'Ein mykenisches Beleuchtungsgerät', in

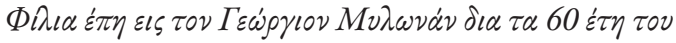

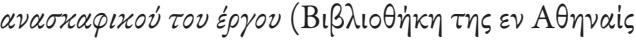

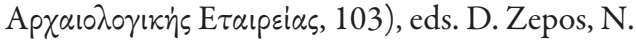
Platon, J. Sakellarakis, J. Travlos \& M. Chatzidakis, Athens, 152-166.

Kilian, K. 1988. 'Ausgrabungen in Tiryns 1982/83. Bericht zu den Grabungen', $A A$ 1988, 105-151.
Kilian, K. 1992. 'Mykenische Heiligtümer der Peloponnes', in Kotinos. Festschrift für Erika Simon, eds. H. Froning, T. Hölscher \& H. Mielsch, Mainz, 10-25.

Knapp, A.B. 1998. 'Mediterranean Bronze Age trade: distance, power and place', in The Aegean and the Orient in the second Millennium. Proceedings of the 50th Anniversary Symposium, Cincinnati, 18-20 April 1997 (Aegaeum, 18), eds. E.H. Cline \& D. Harris-Cline, Liège \& Austin, 193-207.

Knapp, A.B. 2000. 'Archaeology, science-based archaeology and the Mediterranean Bronze Age metals trade', EJA $3: 1,31-56$.

Krzyszkowska, O. 2005. Mycenaean ivories from Tiryns (Tiryns, XIII), Mainz, 179-213.

Krzyszkowska, O. \& R. Morkot 2000. 'Ivory and related materials', in Ancient Egyptian materials and technology, eds. P.T. Nicholson \& I. Shaw, Cambridge, 320-331.

Kostoula, M. \& J. Maran, 2012. 'A group of animal-headed faience vessels from Tiryns', in All the wisdom of the East. Studies in Near Eastern archaeology and history in honor of Eliezer D. Oren (Orbis Biblicus et Orientalis, 255), eds. G. Lehmann, Z. Talshir, M. Gruber \& S. Ahituv, Fribourg, 193-234.

Kuijpers, M.G.H. 2012. 'The sound of fire, taste of copper, feel of bronze and colours of the cast: sensory aspects of metalworking technology', in Embodied knowledge: Historical perspectives on technology and belief, eds. M.L.S. Sørensen \& K. Rebay-Salisbury, Oxford, 137-150.

Laffineur, R. 2005. 'Imports/exports in the Eastern Mediterranean: for a specific methodology', in EMPORIA. Aegeans in the Central and Eastern Mediterranean. Proceedings of the 10th International Aegean Conference, Athens, 14-18 April 2004 (Aegaeum, 25), eds. R. Laffineur \& E. Greco, Liège \& Austin, 53-58.

Lapatin, K.D.S. 2001. Chryselephantine statuary in the ancient Mediterranean world, Oxford.

Legarra Herrero, B. 2011. 'New kid on the block: The nature of the first systemic contact between Crete and the Eastern Mediterranean around 2000 BC', in Interweaving worlds. Systemic interactions in Eurasia, 7th to 1st millennia BC. Papers from a conference in memory of Professor Andrew Sherratt, eds. T.C. Wilkinson, S. Sherratt \& J. Bennet, Oxford, 266-281. 
Leroi-Gourhan, A. 1964-1965. Le geste et la parole, vol. 1. Technique et langage; vol. 2. La mémoire et les rythmes, Paris.

Lindblom, M. 2001. Marks and makers. Appearance, distribution and function of Middle and Late Helladic manufacturers' marks on Aeginetan pottery (SIMA, 128), Jonsered.

Maran, J. 2004a. 'The spreading of objects and ideas in the Late Bronze Age Eastern Mediterranean: two case examples from the Argolid of the 13th and 12th centuries BCE', BASOR 336, 11-30.

Maran, J. 2004b. 'Architektonische Innovation im spätmykenischen Tiryns: Lokale Bauprogramme und fremde Kultureinflüsse', in Althellenische Technologie und Technik. Tagung Oblstadt 21.-23.03.2003, ed. A. Kyriatsoulis, Weilheim, 261-286.

Maran, J. 2008. 'Forschungen in der Unterburg von Tiryns 2000-2003', AA 2008, 35-111.

Maran, J. 2010. 'Tiryns', in The Oxford handbook of the Bronze Age Aegean, ed. E.H. Cline, Oxford, 722-734.

Maran, J. 2012. 'Ceremonial feasting equipment, social space and interculturality in post-palatial Tiryns', in Materiality and social practice. Transformative capacities of intercultural encounters. Papers of the conference, Heidelberg, 25-27 March 2010, eds. J. Maran \& P. Stockhammer, Oxford, 121-136.

McGovern, P.E. 1989. 'Ceramics and craft interaction: a theoretical framework, with prefatory remarks', in Cross-craft and cross-cultural interactions in ceramics (Ceramics and Civilization, IV), eds. P.E. McGovern, M.D. Notis \& W.D. Kingery, Westerville OH, 1-11.

Michaelidou, A. \& K. Voutsa 2005. 'Merchants and merchandise: humans as commodity in Aegean and Oriental societies', in EMPORIA. Aegeans in the Central and Eastern Mediterranean. Proceedings of the 10th International Aegean Conference, Athens, 14-18 April 2004 (Aegaeum, 25), eds. R. Laffineur \& E. Greco, Liège \& Austin, 17-28.

Moran, W.L. 1992. The Amarna letters, Baltimore.

Mossman, S. 2000. 'Mycenaean age lead: a fresh look at an old material', in Trade and production in premonetary Greece: Acquisition and distribution of raw materials and finished products, Proceedings of the 6th International Workshop, Athens 1996 (SIMA-PB, 154), eds. C. Gillis, C. Risberg \& B. Sjöberg, Jonsered, 85-119.
Muhly, J.D. 1993. 'Early Bronze Age tin and the Taurus', AJA $97: 2,239-253$.

Muhly, J.D. 2009. 'Oxhide ingots in the Aegean and in Egypt', in Oxhide ingots in the Central Mediterranean, eds. F. Lo Schiavo, J.D. Muhly, R. Maddin \& A. Guimlia-Mair, Roma, 17-40.

Naji, M. \& L. Douny 2009. 'Editorial', in Journal of Material Culture 14:4, 411-432.

Newhard, J.M.L. 2003. Aspects of local Bronze Age economies: Chipped stone acquisition and production strategies in the Argolid, Greece, PhD thesis, University of Cincinnati.

Nightingale, G. 2008. 'Tiny, fragile, common, precious. Mycenaean glass and faience beads and other objects', in Vitreous materials in the Late Bronze Age Aegean (Sheffield Studies in Archaeology, 9), eds. C.M. Jackson \& E.C. Wager, Oxford, 64-104.

Oxford English Dictionary: www.oed.com, accessed $12 / 05 / 2012$.

Panagiotaki, M. 2008. 'The technological development of Aegean vitreous materials in the Bronze Age', in Vitreous materials in the Late Bronze Age Aegean (Sheffield Studies in Aegean Archaeology, 9), eds. C.M. Jackson \& E.C. Wager, Oxford, 34-63.

Panagiotopoulos, D. 2012. 'Encountering the foreign. (De-) constructing alterity in the archaeologies of the Bronze Age Mediterranean', in Materiality and social practice. Transformative capacities of intercultural encounters. Papers of the conference, Heidelberg, 25-27 March 2010, eds. J. Maran \& P. Stockhammer, Oxford, 51-60.

Panitz-Cohen, N. 2006. “'Off the wall”: Wall brackets and Cypriots in Iron Age I Israel', in "I will speak the riddles of ancient times": Archaeological and historical studies in honor of Amihai Mazar on the occasion of his sixtieth birthday, eds. P. de Miroschedji \& A.M. Maeir, Winona Lake, 613-636.

Pfaffenberger, B. 1992. 'Social anthropology of technology', Annual Review of Anthropology 21, 491-516.

Pfaffenberger, B. 1998. 'Mining communities, chaînes opératoires and sociotechnical systems', in Social approaches to an industrial past. The archaeology and anthropology of mining, eds. A.B. Knapp, V. Pigott \& E.W. Herbert, London, 291-300. 
Philipps, J. 2012. 'On the use and re-use of jewellery elements', in KOSMOS. Jewellery, adornment and textiles in the Aegean Bronze Age. Proceedings of the 13th International Aegean Conference, University of Copenhagen, Danish National Research Foundation's Centre for Textile Research, 21-26 April 2010 (Aegaeum, 33), eds. M.-L. Nosch \& R. Laffineur, Leuven \& Liège, 483-491, pl. CXXIII.

Philippakis, S.E., V. Perdikatsis \& T. Paradellis 1976. 'An analysis of blue pigment from the Greek Bronze Age', Studies in Conservation 21, 143-153.

Pigott, V.C. 2011. 'Sources of tin and the tin trade in southwest Asia: recent research and its relevance to current understanding,' in Metallurgy: Understanding how, learning why. Studies in honor of J.D. Mubly (Prehistory Monograph, 29), eds. P.P. Betancourt \& S.C. Ferrence, Philadelphia, 273-291.

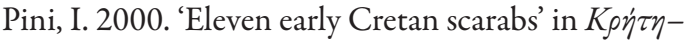

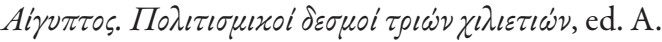
Karetsou, Athens \& Heraklion, 107-113.

Platon, E.M. 1988. The workshops and working areas of Minoan Crete. The evidence of the palace and town of Zakros for a comparative study, $\mathrm{PhD}$ thesis, University of Bristol.

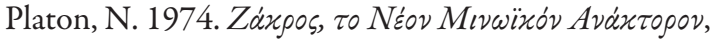
Athens.

Porada, E. 1981-1982. 'The cylinder seals found at Thebes in Boeotia', AfO 28, 1-70.

Pulak, C. 2010. 'Ulu Burun shipwreck', in The Oxford handbook of the Bronze Age Aegean, ed. E.H. Cline, Oxford, 862-876.

Rahmstorf, L. 2008. Kleinfunde aus Tiryns aus Terrakotta, Stein, Bein und Glas/Fayence vornehmlich aus der Spätbronzezeit, Forschungen und Berichte (Tiryns, XVI), Wiesbaden.

Sakellarakis, Y. 1990. 'The fashioning of ostrich-egg rhyta in the Creto-Mycenaean Aegean', in Thera and the Aegean world III, vol. 1. Proceedings of the Third International Congress, Santorini, Greece, 3-9 September 1989, eds. D.A. Hardy, C.G. Doumas \& Y.A. Sakellarakis, London, 285-308.

Schlanger, N. 1994. 'Mindful technology: unleashing the chaine opératoire for an archaeology of mind', in The ancient mind. Elements of cognitive archaeology, eds. C. Renfrew \& E.B.W. Zubrow, Cambridge, 143-151.
Sennett, R. 2008. The craftsman, London.

Shalem, A. 2004. The oliphant. Islamic objects in historical context, Leiden \& Boston.

Shelmerdine, C.W. 2001. 'Review of the Aegean Prehistory VI: the palatial Bronze Age of the southern and central Greek mainland', in Aegean prehistory - A review (AJA Suppl., 1), ed. T. Cullen, Boston, 329-381.

Shortland, A.J. 2000. Vitreous materials at Amarna. The production of glass and faience in 18th Dynasty Egypt (BAR-IS, 827), Oxford.

Thomas, N.R. 2012. 'Adorning with the brush and burin: cross-craft in Aegean ivory, fresco, and inlaid metal', in KOSMOS. Jewellery, adornment and textiles in the Aegean Bronze Age. Proceedings of the 13th International Aegean Conference, University of Copenhagen, Danish National Research Foundation's Centre for Textile Research, 21-26 April 2010 (Aegaeum, 33), eds. M.-L. Nosch \& R. Laffineur, Leuven \& Liège, 755-764, pls. CLXXVII-CLXXIX.

Tournavitou, I. 1988. 'Towards an identification of a workshop space', in Problems in Greek prehistory. Papers presented at the Centenary Conference of the British School of Archaeology at Athens, Manchester, April 1986, eds. E.B. French \& K.A. Wardle, Bristol, 447-467.

Tournavitou, I. 1995. The ivory houses at Mycenae (BSA Suppl., 24), London.

Tropper, J. \& J.-P. Vita 2011. 'Die Keilalphabetische Inschrift aus Tiryns', UgaritF 42, 693-695.

Tykot, R.H. 2011. 'Obsidian finds on the fringes of the Central Mediterranean: exotic or eccentric exchange?', in Exotica in the prehistoric Mediterranean, ed. A. Vianello, Oxford, 33-44.

Tylekote, R.F. 1982. 'The Late Bronze Age: copper and bronze metallurgy at Enkomi', in Early metallurgy in Cyprus, 4000-500 BC. Acta of the International Archaeology Symposium, Larnaca, Cyprus, 1-6 June 1981, eds. J.D. Muhly, R. Maddin \& V. Karageorghis, Nicosia, 81-103.

Tzonou-Herbst, I. 2002. A contextual analysis of Mycenaean terracotta figurines, $\mathrm{PhD}$ thesis, University of Cincinnati. 
van Dommelen, P. 2006. 'Colonial encounters. Material culture and post-colonial theory in colonial situations', in Handbook of material culture, eds. C. Tilley, W. Keane, S. Küchler, M. Rowlands \& P. Spyer, London, $104-124$

van Dommelen, P. \& M. Rowlands 2012. 'Material concerns and colonial encounters', in Materiality and social practice. Transformative capacities of intercultural encounters. Papers of the conference, Heidelberg, 25-27 March 2010, eds. J. Maran \& P. Stockhammer, Oxford, 20-31.

Van Lokeren, S. 2000. 'Experimental reconstruction of the casting of copper "oxhide" ingots', Antiquity 74:284, $275-276$.

van Wijngaarden, G.J. 2012. 'Trade goods reproducing merchants? The materiality of Mediterranean Late Bronze Age exchange', in Materiality and social practice. Transformative capacities of intercultural encounters. Papers of the conference, Heidelberg, 25-27 March 2010, eds. J. Maran \& P. Stockhammer, Oxford, $61-72$.

Varti-Matarangas, M., D. Matarangas \& G. Panagidis 2002. 'Study of the lithofacies of the building stones of the Tiryns Acropolis monuments (Greece)', in Interdisciplinary studies on ancient stone. ASMOSIA VI. Proceedings of the Sixth International Conference of the 'Association for the Study of Marble and Other Stones in Antiquity'. Venice, June 15-18, 2000, ed. L. Lazzarini, Venezia, 477-484.

Vetters, M. 2009. Die spätbronzezeitlichen Terrakotta-Figurinen aus Tiryns - Überlegungen zu religiös motiviertem Ritualverhalten in mykenischer Zeit anhand von Kontextanalysen ausgewählter Siedlungsbefunde, $\mathrm{PhD}$ thesis, Universität Heidelberg.

Vetters, M. 2011a. 'Thou shalt make many images of thy gods - a chaine opératoire approach to Mycenaean religious rituals based on iconographic and contextual analyses of plaster and terracotta figures', in Tracing prehistoric social networks through technology. A diachronic perspective on the Aegean, ed. A. Brysbaert, London, 30-47.

Vetters, M. 2011b. 'A clay ball with a Cypro-Minoan inscription from Tiryns', AA 2011:2, 1-49.

Vetters, M. 2012. 'Die spätbronzezeitlichen Terrakotta-Figurinen aus Tiryns - Überlegungen zu religiös motiviertem Ritualverhalten in mykenischer Zeit anhand von Kontextanalysen ausgewählter Siedlungsbefunde', Archäologisches Nachrichtenblatt 2012:1, 28-37.
Vetters, M. forthcoming. 'From passive objects and discard patterns to enacted rituals? Contextualizing Mycenaean terracotta figurines', in Actes du Colloque de Lille 'Figurines en contexte', Lille, décembre 2011 et Actes de la réunion 'Silent Participants', Philadelphie, janvier 2012, ed. A. Muller.

Vetters, M. \& A. Brysbaert, forthcoming. 'Mirroring the Mediterranean? Artisanal networking in 12th century BCE Tiryns', in The Mediterranean mirror - Cultural contacts in the Mediterranean Sea between 1200 and 750 B.C., Proceedings of the International Conference, Heidelberg, 6-8 October 2012, eds. A. Babbi, F. Bubenheimer, B. Marín-Aguilera \& S. Mühl.

Vianello, A. 2011a. 'Introduction', in Exotica in the prehistoric Mediterranean, ed. A. Vianello, Oxford, vii-viii.

Vianello, A., ed. 2011b. Exotica in the prehistoric Mediterranean, Oxford.

Vickers, M. 1989. 'The cultural context of ancient Greek ceramics: An essay in skeuomorphism', in Cross-craft and cross-cultural interactions in ceramics (Ceramics and Civilization, IV), eds. P.E. McGovern, M.D. Notis \& W.D. Kingery, Westerville, OH, 45-63.

Vickers, M. \& D. Gill 1994. Artful crafts. Ancient Greek silverware and pottery, Oxford.

Voutsaki, S. 1995. 'Value and exchange in pre-monetary societies. Anthropological debates and Aegean archaeology', in Trade and production in pre-monetary Greece: Aspects of trade, Proceedings of the Third International Workshop, Athens 1993 (SIMA-PB, 134), eds. C. Gillis, C. Risberg \& B. Sjöberg, Jonsered, 7-17.

Voutsaki, S. 1997. 'The creation of value and prestige in the Aegean Late Bronze Age', Journal of European Archaeology 5:2, 34-52.

Wendel, W. \& G. Markl 1999. 'Lavrion: Mineralogische Klassiker und Raritäten für Sammler', Lapis 24:7/8, 34-52.

Yener, A.K., P.B. Vandiver \& L. Willies 1993. 'Reply to J.D. Muhly "Early Bronze Age tin and the Taurus", $A J A$ 97:2, 255-264.

Zwicker, U. 1985. 'Investigations of samples from the metallurgical workshops at Kition', in Excavations at Kition V. The Pre-Phoenician levels, Part I, eds. V. Karageorghis \& M. Demas, Nicosia, 403-429. 